\title{
Soil Amendments and Biostimulants from the Hydrothermal Processing of Spent Coffee Grounds
}

\author{
Jackie Massaya $^{1} \cdot$ Ben Mills-Lamptey ${ }^{2} \cdot$ Christopher J. Chuck $^{1}[$
}

Received: 18 August 2021 / Accepted: 14 January 2022 / Published online: 1 February 2022

(c) The Author(s) 2022

\begin{abstract}
Purpose Use of spent coffee grounds (SCG) in horticulture has deleterious effects on plant health and yields, suggesting that processing of SCG is necessary prior to field application. To this end, two products of an SCG based biorefinery were investigated: primary chars from the hydrothermal carbonisation (HTC) of SCG and enzymatic protein hydrolysates.

Methods Primary chars were produced under various HTC regimes from raw SCG, and alkaline pre-treated SCG. Primary chars were evaluated in germination toxicity tests and under soil stress conditions using Arabidopsis thaliana (Arabidopsis). Proteolytic enzymes were screened in production of SCG protein hydrolysates; biostimulant activity in the growth of Saccharomyces Cerevisiae, germination of Arabidopsis thaliana under normal and cold conditions and auxin-like activity was assessed.

Results Toxicity assays of primary chars with land cress (Barbarea verna L.) showed a maximum 35\% increase in root length, relative to the control. In Arabidopsis growth trials, outstanding performances were recorded at 100 t/ha for primary chars produced from alkaline pre-treated SCG: rosette diameter and dry weight increased by 531 and 976\%, respectively, relative to the control. SCG protein hydrolysate from Bacillus lichenformis proteolysis (glycine present at $47 \%$ of total) gave 140\% increase in Arabidopsis seeds with expanded cotyledons, relative to the control. Auxin-like activity was also measured in the extracts.
\end{abstract}

Conclusion Cascade process design was used to valorise a major waste stream. Removal of phytotoxic components from SCG hydrochars enhanced plant growth, while biostimulant activity of SCG protein hydrolysates was observed.

\section{Graphical Abstract}

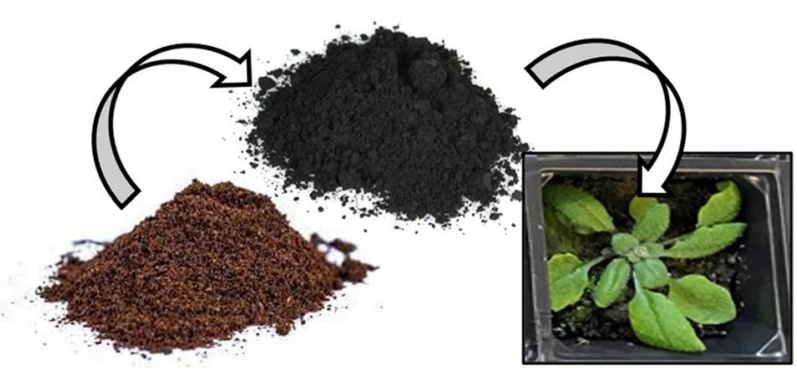

Keywords Spent coffee grounds $\cdot$ Coffee $\cdot$ Fertiliser $\cdot$ Hydrochar

Christopher J. Chuck

c.chuck@bath.ac.uk

1 Department of Chemical Engineering, University of Bath, Bath BA2 7AY, UK

2 Bio-Bean Ltd, Unit 4002, Alconbury Weald Enterprise Park, Alconbury, Huntingdon PE28 4WX, UK

\section{Abbreviations}

SCG Spent coffee grounds

PC Primary chars

HTC Hydrothermal carbonisation

PE SCG Alkaline pre-treated SCG

PE PC Primary char derived from alkaline pre-treated SCG 
RAW PC Primary char from raw SCG

SCG PH SCG protein hydrolysate

IAA Indole- 3 acetic acid

CGA Chlorogenic acid

\section{Statement of Novelty}

Spent coffee grounds (SCG) comprise of complex protein, lignocellulosic and bioactive fractions. As such SCG has been increasingly researched for further valorisation with the majority of research focussing on the development of fuels and bulk chemicals. However, multiple technoeconomic assessments have suggested this to be unviable. Instead, the resulting products could be used as a higher value fertiliser or biostimulant. While SCG has been used directly as a fertiliser, recent work has also demonstrated how unsuitable this approach is for higher plants. In this paper, we demonstrate for the first time, that alkaline hydrolysis of the protein fraction, converting the rest of the biomass into a hydrochar by HTC, followed by a polar extraction to remove phytotoxic components, can produce higher value, high performance additives for horticulture.

\section{Introduction}

Treatment of soil with carbonaceous material such as biochar is a traditional strategy towards ameliorating soil quality. Biochars are highly carbonised polyaromatic solids produced from biomass pyrolysis under inert or partially oxygenated conditions $\left(\mathrm{T}=300-700{ }^{\circ} \mathrm{C}\right)$ or gasification. More recently hydrochars, the slurry product from the hydrothermal carbonisation (HTC) of biomass under comparatively milder processing conditions $\left(\mathrm{T}=180-260{ }^{\circ} \mathrm{C}\right.$ ) in up to $95 \%$ vol water, have been highlighted as suitable soil amendments. Typically hydrochars are produced from biomass with high moisture content such as algae, food waste, sewage sludge and spent coffee grounds. Morphological and physicochemical properties are influenced by feedstock and processing conditions, yet differ vastly between char types: the surface of hydrochars feature a volatile spherical secondary char phase condensed within a porous fibrous primary char network, as well as relatively lower ash contents [1]. However, the volatile phase is attributed to the observed phytotoxicity of hydrochar, necessitating post-treatments such as composting and thermal processing prior to soil application [2-4]. As horticultural substrates, both hydrochars and biochars have been highlighted for improving the nutrient uptake, water holding capacity, $\mathrm{N}$-retention, and crop productivity [5-7]. In terms of sustainability, production of hydrochars and biochars beneficially utilises waste streams from the agricultural, industrial, food-processing, and municipal sectors as well as promoting carbon sequestration $[8,9]$.

Whilst bio/hydrochars are noted soil improvers, biostimulants are an emerging class of horticultural substrates which, when applied to plants, increase crop quality, nutrient efficiency and stress tolerance [10]. Biostimulants can be used along with or as substitutes for fertilisers, and are thus a sustainability measure against the wholesale use of fossil-based agrochemicals. Originating from biological sources, biostimulants are defined by their function rather than composition, where natural processes of the plant are supported and stimulated by extracts derived from plant and microbial sources. Though formulations may include essential plant nutrients, growth regulators or phytoprotective components, biostimulants are distinguishable from fertilisers and soil amendment by the emergent action of synergistic components and are nonetheless applied to the foliar or rhizosphere in doses low enough (typically less than 5\%) to negate a fertiliser effect $[11,12]$.

Non-microbial biostimulant formulations typically include protein hydrolysates $(\mathrm{PH})$, humic acids and seaweed extracts. Protein hydrolysates are predominately comprised of free amino acids and peptides and are extracted from animal or plant agro-industrial by products via chemical or enzymatic hydrolysis. Proteolytic enzymes are advantageous over chemical hydrolysis as their use prevents racemisation of amino acids in addition to preserving acid/alkaline/heat labile components such as tryptophan and oligosaccharides and vitamins [13]. For example, when applied to the foliar or rhizosphere of plants, a legume- based protein hydrolysate biostimulant 'Trainer [' has reportedly improved nutrient uptake and fresh yield of crops such as spinach corn, tomatoes and dwarf peas through promotion of auxin and/or gibberellinlike activity $[14,15]$.

Spent coffee grounds (SCG), the solid residues of the beverage brewing process, have been investigated for their effect on the yield and nutrient profile of several plants and crops. However, the presence of low molecular weight polyphenols, condensed tannins and alkaloids such as caffeine are purportedly responsible for the anti-nutritional and anti-physiological effects on crop productivity when fresh SCG is directly applied to soils [16]. This inhibitory effect on growth is somewhat ameliorated by a concomitant increase in micronutrients brought about via chelation of minerals by SCG melanoidins and polyphenols. A recent investigation by Mata et al. sought to mediate between the decreased productivity/increased nutritional quality observed for an SCG bio-amendment by reducing phytotoxic constituents prior to soil amendment, so-called 'stabilisation'. However, it was discovered that whilst high temperature biocharization, vermi-composting and composting significantly reduced the polyphenolic content of 


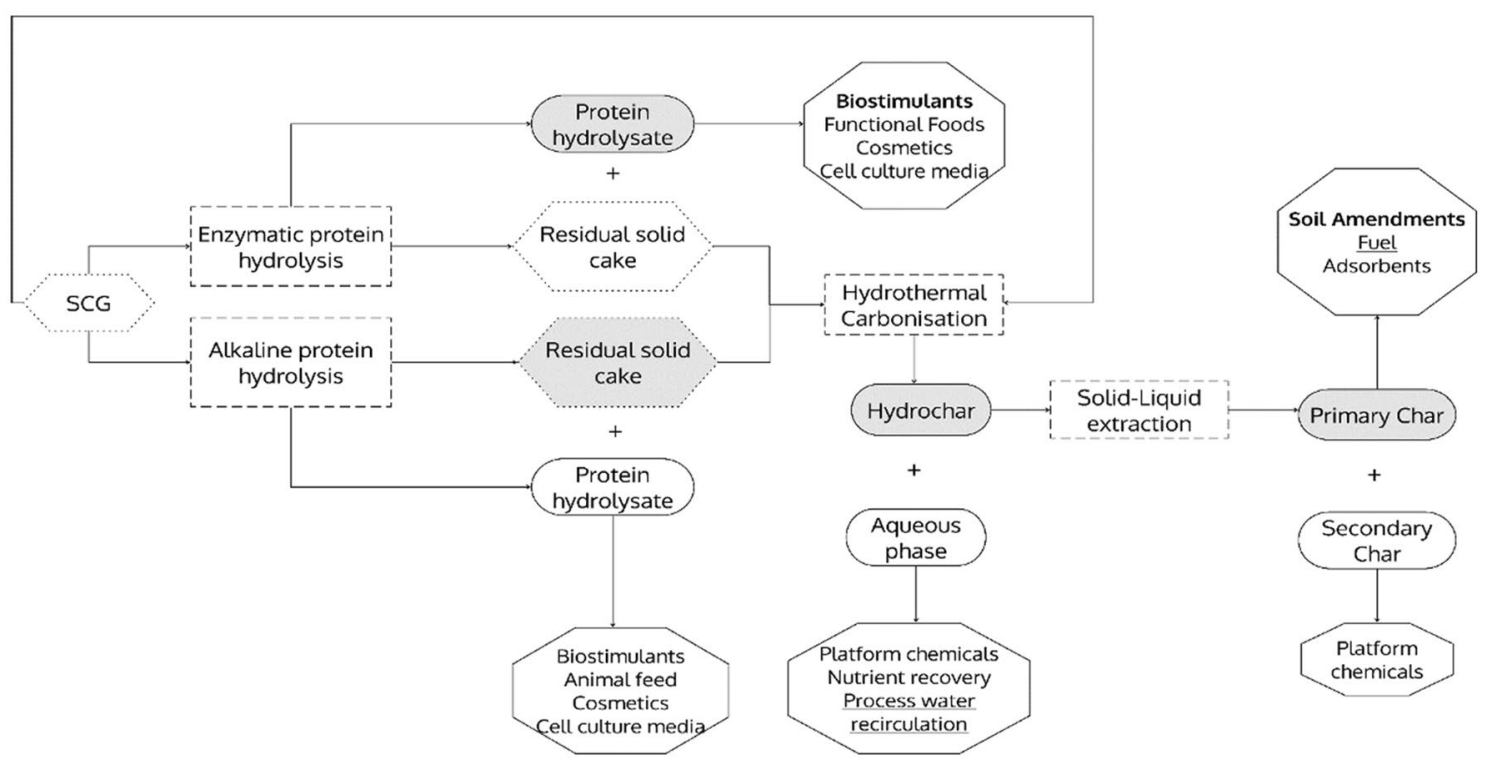

Fig. 1 Spent coffee grounds biorefinery scheme, where enzymatic and alkaline hydrolysis pre-treatment platforms are integrated with hydrothermal carbonisation and a solid-liquid extraction post-treatment for production of several outputs. Shaded shapes denote process outputs that have undergone product development in this study; horticultural amendments of this study are in bold-type whilst underlined are previously explored products by this group [20]

\section{Material and Methods}

the bio-amendments, imparting improved yields relative to fresh SCG controls, the $\mathrm{Zn}, \mathrm{Fe}$ and $\mathrm{Cu}$ content of lettuce were reduced substantially. The authors recommend development of mixtures of fresh or pre-treated SCG with NPK fertilisers to maximise crop yield and nutritional quality. A subsequent study by the same group, working within the circular economy framework, found that an enriched presence of polyphenols in hydrochar products from the HTC of SCG replicated inhibitory behaviour observed for fresh SCG- with greater potential for mobilization of mineral elements [17, 18].

In this investigation, a previously reported SCG-based biorefinery was modified and two major products were utilised to yield SCG-based substrates for horticultural amendments (Fig. 1) [19]. Specifically, SCG hydrochar products derived from untreated and alkaline pre-treated SCG feedstocks were assessed for their influence on the germination of Barbarea verna L. (land cress) and rosette growth of Arabidopsis thaliana. To the best of our knowledge, this is the first study to explore SCG primary hydrochars as soil amendments. In addition, inclusion of an enzymatic hydrolysis step within the biorefinery for production of an SCG protein hydrolysate (SCG $\mathrm{PH}$ ) biostimulant was explored. Biostimulant potential was assessed through performance of SCG PH in the continuous growth of Saccharomyces cerevisiae, germination of Arabidopsis under cold and normal growth conditions and auxin-like activity.

\section{Raw Materials and Chemicals}

Spent coffee grounds (SCG) feedstock were supplied by Biobean at $6.79 \%$ moisture content as received and stored at $4{ }^{\circ} \mathrm{C}$ until use. Sandy-Loam topsoil was supplied by Melcourt (Topsoil ${ }^{\mathrm{TM}}$ Blended Loam). Arabidopsis thaliana ecotype Col-0 was used in climatic chamber trial and seed germination assays ("Arabidopsis thaliana Climatic Chamber Trial" and "Evaluation of the effect of SCG PH on the growth of $S$. cerevisiae" sections respectively). Protex enzymes were supplied in a screening kit by ChiralVision B.V. Sacharromyces cerevisae BY4741 (MATa his $3 \Delta 1$ leu $2 \Delta 0$ met $15 \Delta 0$ ura3 $\Delta 0$ ) was grown in bioassays with enzymatic protein hydrolysates. Barbarea verna L. (land cress) seeds were supplied by Unwins Seeds Ltd.

SCG, pretreated SCG, hydrochar and primary char moisture content was determined using a thermogravimetric mass analyser (TGA, Setaram Setsys Evolution TGA 16/18) with the following program: samples were heated to $105{ }^{\circ} \mathrm{C}$ (ramp rate $=20^{\circ} \mathrm{C} / \mathrm{min}$ ) and held for $35 \mathrm{~min}$ under argon atmosphere. Weight loss during this period was interpreted as the evaporation of water within the solid matrix, expressed as a percentage of the starting material. Duplicate analyses were made.

Bridgeway was supplied by Interagro UK Ltd, all other reagents and chemicals were supplied by Sigma Aldrich or Fisher Scientific and were reagent or analytical grade. 


\section{SCG-Based Soil Amendments}

\section{Hydrothermal Carbonisation Regimes Pre- and Post-Treatments}

Alkaline pre-treatments were conducted as follows: $30-40 \mathrm{~g}$ of SCG and $300-400 \mathrm{~mL}$ of $1 \mathrm{M} \mathrm{NaOH}$ were heated at $95{ }^{\circ} \mathrm{C}$ for $4 \mathrm{~h}$. After each extraction, solids were retained and washed with deionised water until the filtrate ran clear. Solids were dried at $60{ }^{\circ} \mathrm{C}$ for $72 \mathrm{~h}$ and stored at room temperature until further analysis and utilisation in HTC experiments.

HTC experiments were carried out according to a previous investigation, using a $300 \mathrm{~mL}$ Hastelloy high-pressure bench top stirred reactor with thermocouple and PID temperature controller (Parr Instruments Company, Illinois, USA) [20]. HTC regimes were as follows: HTC 217 $\left(\mathrm{T}=217^{\circ} \mathrm{C}, \mathrm{t}=1 \mathrm{~h}\right) ; \mathrm{HTC} 223\left(\mathrm{~T}=223{ }^{\circ} \mathrm{C}, \mathrm{t}=2.75 \mathrm{~h}\right) ; \mathrm{HTC}$ $260\left(\mathrm{~T}=260{ }^{\circ} \mathrm{C}, \mathrm{t}=4.5 \mathrm{~h}\right)$. SCG $(20 \mathrm{~g})$ were loaded with $200 \mathrm{~mL}$ deionised water into the reaction vessel, which was sealed and heated to desired run temperatures (approximate ramp time was $45 \mathrm{~min}$ ). Residence time was taken once internal temperature had reached the desired run temperature. After the runs, solids were filtered off, (Fisherbrand® QL100 papers), and mass and $\mathrm{pH}$ of the aqueous phase was immediately recorded. Liquids were stored at $-21^{\circ} \mathrm{C}$, solids were dried at $60{ }^{\circ} \mathrm{C}$ for $48 \mathrm{~h}$, weighed and stored at room temperature.

Primary chars were retained from hydrochars using methanol/ acetone (50:50 v/v) extraction of secondary chars. Solvents were applied until the filtrate ran clear, after which the solids were dried at room temperature and then at $60{ }^{\circ} \mathrm{C}$ for $16 \mathrm{~h}$. Secondary chars were retained through solvent removal under reduced pressure and were subsequently dried at room temperature. Chars were weighed and stored at room temperature.

\section{Characterisation of SCG-Based Soil Amendments}

SCG, PE and HTC solids were characterised via proximate and ultimate analysis. Ultimate analyses of carbon, hydrogen, nitrogen content were carried out according to BS EN ISO 9001:2015- oxygen content was determined by difference. Moisture content, proximate analysis of fixed carbon (FC), volatile matter (VM) and ash content, was carried out using a Setaram -Setsys Evolution thermogravimetric (TGA) 16/ 18 analyser as previously reported [21]. Argon (moisture content and VM) and air (FC) carrier gases (flow rate $=50 \mathrm{~mL} / \mathrm{min}$ ) were used along argon protective gas (20 $\mathrm{mL} / \mathrm{min})$. For each analysis: $10-20 \mathrm{mg}$ of sample was loaded into an alumina crucible, and the sample was heated under Ar to $105^{\circ} \mathrm{C}$ at a rate of $20^{\circ} \mathrm{C} / \mathrm{min}$, where it was held for $30 \mathrm{~min}$ to allow for the complete evaporation of moisture.
The sample was then heated to $900{ }^{\circ} \mathrm{C}$ at $16{ }^{\circ} \mathrm{C} / \mathrm{min}$ under $\mathrm{Ar}$, held for $7 \mathrm{~min}(\mathrm{VM})$, followed by an isotherm in air at $800{ }^{\circ} \mathrm{C}$ for $30 \mathrm{~min}$ (FC).

Atomic absorption or inductively coupled plasma (ICP) analysis were used to characterise elemental composition ( $\mathrm{Ca}, \mathrm{Mg}, \mathrm{Mn}, \mathrm{B}, \mathrm{Cu}, \mathrm{Fe}, \mathrm{Zn}, \mathrm{P}, \mathrm{Na}, \mathrm{K}$ ) and cation exchange capacity in Topsoil and 100 t/ha Topsoil- SCG PC blends. Organic matter and nitrogen content was determined by Dumas method using CNS analyser. $\mathrm{pH}$, electrical conductivity (EC) and all analyses were conducted in a UKAS accredited lab (Lancrop Laboratories).

\section{Soil Less Petri Dish Assay}

PE, SCG and primary char products were sieved $(<355 \mu \mathrm{m}$ screen) and added at 0 (control), 0.25, 0.5, 1.0 and $2.0 \mathrm{~g}$ dose rates (equivalent to $0,5,10,20$ and $40 \mathrm{t} / \mathrm{ha}$ volume basis at $10 \mathrm{~cm}$ soil depth, assuming a bulk density of $1.6 \mathrm{~g} / \mathrm{cm}^{3}$ ) to petri dishes containing filter paper. After surface sterilization with hydrogen peroxide ( $30 \% \mathrm{w} / \mathrm{w})$ for $15 \mathrm{~min}$ and rinsing with 3 volumes of deionised water, 10 land cress seeds were evenly distributed within the solids before addition of $20 \mathrm{~mL}$ sterile deionised water. Dishes were covered and incubated in the dark at $25^{\circ} \mathrm{C}$ for 7 days. Number of germinated seeds and root lengths were then recorded, and each experiment was carried out in triplicate. Germination rate was calculated as proportion of germinated seeds out of total seeds, expressed as a percentage.

\section{Arabidopsis thaliana (Arabidopsis) Growth Trial}

Blends of SCG primary chars and topsoil ( $<6 \mathrm{~mm}$ particle diameter, bulk density $=1.2 \mathrm{~g} / \mathrm{cm}^{3}$ ) were prepared at 0,10 , 20,50 and $100 \mathrm{t} / \mathrm{ha}$, thoroughly mixed and $60 \mathrm{~g}$ of each blend was added to a cell of a 15 cell seed tray. After saturating blends with water, previously 3-day cold-stratified Arabidopsis Col-0 seeds were sown in each cell $(\times 3)$ and trays were placed in climatic chambers with the following parameters: $16 \mathrm{~h} \mathrm{light}$ at $120 \mu \mathrm{mol} / \mathrm{s}, 21{ }^{\circ} \mathrm{C}$. Adequate soil moisture was maintained through daily watering and after five days, number of seeds per cell was reduced to one. Arabidopsis were grown for 28 days after which rosettes were harvested and leaf number, rosette diameter, fresh and dry weight were measured. Experiments were conducted in triplicate.

\section{SCG-Based Biostimulants (SCG PH)}

\section{Enzymatic Hydrolysis of SCG}

SCG PH were obtained in enzyme screening experiments as follows: $5 \mathrm{~mL}$ of proteolytic enzyme was added to $0.5 \mathrm{~g}$ of SCG and after optimal temperature (given by supplier) 
was reached, hydrolyses were carried out for $1 \mathrm{~h}$. $\mathrm{pH}$ was recorded before and during hydrolyses, and $0.5 \mathrm{M} \mathrm{NaOH}$ was added until a constant $\mathrm{pH}$ was measured. Volume of $\mathrm{pH}$ was recorded and used in the $\mathrm{pH}$ stat method to calculate degree of hydrolysis (DH). After $1 \mathrm{~h}$, enzymes were denatured by heating the mixture to $90{ }^{\circ} \mathrm{C}$ and the solids were filtered off. The initial filtrate mass and mass after drying at $95^{\circ} \mathrm{C}$ to constant weight were recorded.

\section{Characterisation of SCG-PH}

Degree of hydrolysis is the percentage of cleaved peptide bonds $(h)$ out of the total available peptide bonds in a $\operatorname{sample}\left(h_{\text {tot }}\right)$, Eq. 1:

$D H(\%)=\frac{100 h}{h_{t o t}}$

DH is calculated using Eq. 2: [22]

$D H(\%)=\frac{100 \cdot V_{b} \cdot N_{b}}{\alpha \cdot M P \cdot h_{t o t}}$

where: $\mathrm{V}_{\mathrm{b}}$ and $\mathrm{N}_{\mathrm{b}}$ are the volume in $\mathrm{mL}$ and normality of base used; $\alpha$ is the average degree of dissociation of the $\mathrm{NH}$ groups (calculated using Eq. 3 and 4); MP is the mass of protein in $\mathrm{g} ; h_{\mathrm{tot}}$ is the total number of peptide bonds in a protein substrate in meqv/g protein (Eq. 5).

$\mathrm{pH}$ and temperature dependent constant, $\alpha$, is calculated as follows:

$\alpha=\frac{10^{p H-p K a}}{1+10^{p H-p K a}}$

where $p K a$ is estimated using Eq. 4 [23]:

$p K a=7.8+\frac{298-T}{298 T} \cdot 2400$

$h_{\text {tot }}$ is calculated based on the amino acids in the sample, according to Eq. 5 [24]:

$h_{\text {tot }}=\sum\left(\frac{\omega(A A)_{i}}{m\left(N_{A A}\right)_{i} \cdot f_{N}} \cdot \frac{1000}{M_{r}(A A)_{i}}\right)$

where: $\omega(\mathrm{AA})_{\mathrm{i}}$ is the amino acid individual mass fraction $(\mathrm{mg} / \mathrm{g}) ; M_{\mathrm{r}}(\mathrm{AA})_{\mathrm{i}}$ is the amino acid molecular mass $(\mathrm{g} / \mathrm{mol})$; $N_{\text {AAi }}$ is the mass of $\mathrm{N}$ in the amino acid $(\mathrm{mg} / \mathrm{g}) ; f_{\mathrm{n}}$ is the nitrogen-to-protein conversion factor, which for SCG is 7.79 [19].

In this work $h_{\text {tot }}$ was calculated as 8.74 meqv/g protein.

Free amino acids in SCG PH were quantified using an Agilent QTOF 6545 with Jetstream ESI spray source coupled to an Agilent 1260 Infinity II Quat pump HPLC. Chromatographic runs were carried out using an Agilent InfinityLab Poroshell 120 HILIC-Z 2.1 $\times 100$ mm, $2.7 \mu \mathrm{m}$ column, with 1260 autosampler and variable wavelength detector (VWD). Run methods were as previously published [19].

\section{Saccharomyces cerevisiae in SCG PH}

Yeast and Arabidopsis assays were adapted from a previously published procedure [25]. 96-well microplate assays were used to monitor the continuous growth of S. cerevisiae. Overnight liquid cultures of yeast in yeast extract, peptone and dextrose media (YPD) were diluted to initial $\mathrm{OD}_{600}$ measurement of 0.01 and added to wells containing 5\% (v/v) SCG PH or Bridgeway solutions in YPD or YPD only (control). Final concentration of yeast was $1 \%(\mathrm{v} / \mathrm{v})$. $\mathrm{OD}_{600}$ measurements were recorded at $30{ }^{\circ} \mathrm{C}$, every $30 \mathrm{~min}$ for 4 days using a FLUOstar Omega microplate reader. Growth rates and max OD data were processed using GrowthRates version 4.0 (Bellingham Research Institute). Assays were conducted in biological and technical triplicates.

\section{Arabidopsis Germination Trials}

MS-solid agar medium (containing $0.8 \%$ phytoagar, Murashige and Skoog (MS) basal salt mixture (0.4\%), sucrose (1\%) and $10 \mathrm{mM}$ MES (2-(N-morpholino) ethanesulfonic acid buffer, adjusted to $\mathrm{pH} 5.5$ with Tris base (tris(hydroxymethyl)aminomethane)) was prepared, sterilised and added to a petri dish $(19.8 \mathrm{~mL})$. Prior to jellification, sterile aliquots of SCG PH or Bridgeway were added at $1 \%(0.2 \mathrm{~mL}, \mathrm{v} / \mathrm{v})$ and evenly distributed- the control was MS-solid medium only (20 mL). Previously surface sterilised Arabidopsis seeds (using 30\% hydrogen peroxide) were emerged in a $0.1 \%$ agarose solution and approximately 100 seeds were uniformly dispensed in each petri-dish. After cold stratification at $4{ }^{\circ} \mathrm{C}$ for 3 days, plates were incubated in the dark at $25^{\circ} \mathrm{C}$ for 9 days (normal conditions) or at $10{ }^{\circ} \mathrm{C}$ for 13 days (cold conditions) and number of seeds with expanded cotyledons were subsequently recorded.

\section{Auxin-Like Activity Assay}

Auxin assays were carried out using land cress seeds, according to a published procedure, based on the Audus test [26]. After surface sterilisation, 10 land cress seeds were distributed on a filter paper placed in a petri-dish and $1.2 \mathrm{~mL}$ of $1 \mathrm{mM} \mathrm{CaSO}_{4}$ (control) or indoleacetic acid (IAA; 10, 1 , 0.1 , and $0.01 \mathrm{ppm}$ solutions) or serially diluted SCG PH and Bridgeway ( 3 concentrations) were added. Seeds were incubated in the dark for 3 days after which root length of germinated seeds were measured and expressed relative to the control. Experiments were conducted in triplicate. 


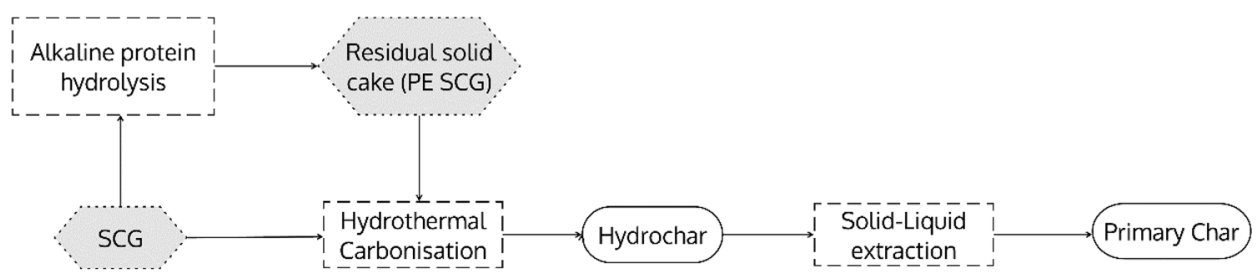

Fig. 2 Simplified scheme of cascade processes used to produce primary chars for spent coffee ground (SCG) based soil amendments. Shaded are the SCG and alkaline pre-treated feedstocks (PE SCG) for hydrothermal carbonisation under three regimes

\section{Statistical Analysis}

One- way analysis of variance (ANOVA) or General Linear Model were used to determine statistically significant differences between group means at 5\% significance level. Procedures and post-hoc tests (Dunnett, Tukey and GamesHowell) were all carried out using Minitab software (version $18)$.

\section{Results and Discussion}

\section{SCG Solids as Soil Amendments}

\section{Characterization of SCG and SCG Derived Bio-Amendment}

SCG hydrochars were produced from the HTC of raw SCG or alkaline pre-treated SCG (PE SCG), in which $1 \mathrm{M}$ $\mathrm{NaOH}$ was used to isolate a protein extract and reduce $\mathrm{N}$ content (Fig. 2), as adapted from our previous work [20]. Mild $(\mathrm{T}=217, \mathrm{t}=1 \mathrm{~h})$, moderate $(\mathrm{T}=223, \mathrm{t}=2.75 \mathrm{~h})$ and severe $(T=260, t=4.5 \mathrm{~h})$ regimes were used to process raw
SCG into hydrochars with modified physicochemical properties. Primary chars were extracted from crude hydrochars using methanol/acetone $(50 / 50, \% \mathrm{v} / \mathrm{v})$. This polar extraction removed the volatile secondary char phase, in which phytotoxic components, such as polyaromatic hydrocarbons are expected to accumulate [27].

The compositional data illustrates the increase in $\mathrm{C}$ and fixed carbon (FC) as a result of the hydrothermal carbonisation of SCG (Table 1). Primary chars are composed of lower volatile matter (VM) and lower $\mathrm{O}$ content relative to their SCG or alkaline extracted PE SCG feedstock. HTC is therefore a good strategy for stabilising carbon and increasing the carbon sequestration potential of second generation (waste) biomass before release into the environment. During HTC, biomass is converted into a more carbonaceous char via two pathways. A complex network of hydrolysis, dehydration and decarboxylation reactions degrade the hemicellulose and cellulose fractions of the biomass into gas (mostly $\mathrm{CO}_{2}$ ) and labile components such as 5-HMF and furfural and organic acids. These reactive intermediates accumulate in the aqueous phase and undergo condensation, polymerisation and aromatization reactions to form liquid biocrude or secondary char deposits within the pores of the unconverted

Table 1 Compositional properties of SCG (RAW SCG), alkaline extracted SCG (PE SCG) and corresponding primary chars (RAW PC and PE $\mathrm{PC}$, respectively) produced under different HTC regimes

\begin{tabular}{|c|c|c|c|c|c|c|c|c|}
\hline \multirow[t]{2}{*}{ Property } & \multicolumn{8}{|l|}{ Sample } \\
\hline & 217 RAW PC & 223 RAW PC & 260 RAW PC & 217 PE PC & 223 PE PC & 260 PE PC & RAW SCG & PE SCG \\
\hline $\mathrm{pH}$ & $3.88 \pm 0.02$ & $3.97 \pm 0.03$ & $4.40 \pm 0.02$ & $3.67 \pm 0.12$ & $3.77 \pm 0.07$ & $3.58 \pm 0.01$ & $5.19 \pm 0.02$ & $4.72 \pm 0.09$ \\
\hline $\mathrm{C}(\%)$ & $60.45 \pm 0.87$ & $66.07 \pm 0.16$ & $72.90 \pm 0.07$ & $51.21 \pm 0.37$ & $58.06 \pm 0.30$ & $73.70 \pm 0.07$ & $54.58 \pm 0.25$ & $47.68 \pm 0.23$ \\
\hline $\mathrm{H}(\%)$ & $5.63 \pm 0.18$ & $5.64 \pm 0.20$ & $5.82 \pm 0.10$ & $6.21 \pm 0.65$ & $5.86 \pm 0.18$ & $5.73 \pm 0.10$ & $7.63 \pm 0.22$ & $7.32 \pm 0.21$ \\
\hline $\mathrm{N}(\%)$ & $3.36 \pm 0.37$ & $3.69 \pm 0.27$ & $4.06 \pm 0.20$ & $0.38 \pm 0.06$ & $0.65 \pm 0.12$ & $0.84 \pm 0.04$ & $2.47 \pm 0.27$ & $0.22 \pm 0.02$ \\
\hline $\mathrm{O}^{\mathrm{a}}$ & $30.57 \pm 0.00$ & $24.60 \pm 0.00$ & $17.23 \pm 0.00$ & $42.21 \pm 0.00$ & $35.42 \pm 0.00$ & $19.73 \pm 0.00$ & $35.32 \pm 0.00$ & $44.79 \pm 0.00$ \\
\hline $\mathrm{C} / \mathrm{N}$ & $17.99 \pm 2.01$ & $17.91 \pm 1.33$ & $17.97 \pm 0.89$ & $135.67 \pm 21.90$ & $88.71 \pm 16.13$ & $88.04 \pm 4.36$ & $22.12 \pm 2.43$ & $216.82 \pm 23.81$ \\
\hline Fixed Carbon (\%) & $61.05 \pm 0.85$ & $61.63 \pm 0.23$ & $54.86 \pm 0.38$ & $34.78 \pm 0.30$ & $34.97 \pm 0.42$ & $37.28 \pm 0.18$ & $25.24 \pm 0.15$ & $28.70 \pm 0.98$ \\
\hline Volatile matter (\%) & $34.49 \pm 0.52$ & $36.20 \pm 0.47$ & $44.20 \pm 0.33$ & $64.09 \pm 0.21$ & $65.00 \pm 0.19$ & $61.65 \pm 0.13$ & $72.15 \pm 0.48$ & $65.15 \pm 0.39$ \\
\hline Ash (\%) & $6.56 \pm 0.37$ & $7.12 \pm 0.70$ & $5.07 \pm 0.71$ & $5.97 \pm 0.50$ & $3.92 \pm 0.62$ & $4.41 \pm 0.05$ & $9.89 \pm 0.33$ & $10.87 \pm 0.61$ \\
\hline $\begin{array}{l}\text { Moisture content } \\
(\%)\end{array}$ & $4.84 \pm 0.05$ & $4.72 \pm 0.03$ & $3.97 \pm 0.04$ & $4.62 \pm 0.05$ & $3.75 \pm 0.01$ & $3.24 \pm 0.01$ & $6.79 \pm 0.08$ & $4.50 \pm 0.16$ \\
\hline
\end{tabular}

${ }^{\mathrm{a}}$ Calculated by difference values are reported on a dry basis (mean \pm sem, $\mathrm{n}=3$ ) 
solid (primary char) [28]. As previously reported, the most severe regime (HTC 260) produced chars with the greatest $\mathrm{C}$ and lowest $\mathrm{O}$ contents, yet for the primary char produced at $260{ }^{\circ} \mathrm{C}$ from the raw feedstock, fixed carbon was lower and volatile matter was higher than the chars produced from raw SCG under mild and moderate regimes. This can be attributed to the greater extent of degradation afforded by the higher temperature (namely, the crystalline structure of cellulose degrades at $220{ }^{\circ} \mathrm{C}$ ) and longer duration of the regime. Retention of the lowest crude hydrochar yield of $49 \%$ in the most severe regime (vs $63 \%$ and $55 \%$ for crude hydrochar products of HTC 217 and 223 respectively) and greatest secondary char yield signifies a higher conversion of biomass into a volatile phase.

Whilst no significant difference in volatile matter and fixed carbon was observed for chars produced from alkaline pre-treated SCG across all the HTC regimes, the proportions were reversed in comparison to the untreated analogues. This is presumably a result of the disruptive action of $\mathrm{NaOH}$ on the morphology of SCG via degradation of polymeric sugars or removal of $\mathrm{N}$ containing components (including proteins, peptides and free amino acids) and fatty acids via saponification. A more porous, open structure is observed for PE SCG, aiding the proliferation of biomass fragmentation into comparatively more reactive char products $[19,20]$.

The $\mathrm{C} / \mathrm{N}$ ratio of a bio-amendment can indicate its potential to mobilize soil $\mathrm{N}$, with ratios lower than 30 linked to greater rates of nitrification, denitrification and nitrate ammonification, depending on the biological availability of C [29]. Consequently, application of organic amendments can influence plant nutrient availability and soil $\mathrm{N}_{2} \mathrm{O}$ emissions [30]. For carbon sequestration, $\mathrm{C} / \mathrm{N}$ ratio is the most significant biochar property impacting native soil organic carbon decomposition [31]. The $\mathrm{C} / \mathrm{N}$ ratio of all primary chars produced from raw SCG feedstock averaged at 17.96: this is almost 7.5-fold lower than the only statistically significant char within the pre-treated SCG feedstock (217 PE primary char, $\mathrm{C} / \mathrm{N}$ ratio $=135.67$, Table 1 ). Thus, the pretreatment is a potential strategy for tuning applications of SCG hydrochars where, depending on the soil type, longer incubation periods with PE chars may favour long term carbon storage and soil conditioning. However, the presence of moderate levels of volatile matter may stimulate soil microbial activity, incurring short term GHG emissions [32]. With their low $\mathrm{C} / \mathrm{N}$, the chars produced from the raw SCG, may perform better as soil fertility enhancers and growing media components by increasing soil $\mathrm{N}$ stores. Additionally, the acidic $\mathrm{pH}$ of the primary chars may indicate suitability as ameliorants of alkaline soils.

\section{Petri-Dish Toxicology Tests}

A preliminary soil-less petri-dish assay was undertaken to rapidly determine the toxicology of SCG and its process derivatives on the germination of Lactuca sativa $\mathrm{L}$. seeds. Raw SCG, alkaline pre-treated (PE) SCG, crude SCG hydrochars and primary chars were modelled as potential bioamendments. Excluding hydrochars produced from the most severe HTC regime, $260 \mathrm{PE}$ and $260 \mathrm{RAW}$, all untreated hydrochars exerted a deleterious effect on seed germination (S1, supplementary data). This result corroborates with previous studies, where the presence of polyphenolic allelochemicals are attributed to the inhibitory effect of SCG bio-amendments on plant biomass growth [16-18, 33]. It is thought that polyphenolic components such as chlorogenic acid (CGA) are phytotoxic through mechanisms including interference with plant metabolic pathways, membrane cell oxidation and immobilisation of soil $\mathrm{N}$ and $\mathrm{P}$ [34]. Caffeine may also present allelopathic activity through prevention of $\mathrm{N}$ mineralization [35]. Yet, SCG polyphenols are thought to enhance mineral uptake of crops through their binding capacity [36, 37]. As hydrochars consist of both a primary and a secondary char phase, where identified secondary char constituents are allelochemicals, removal of this phase should reduce the observed inhibition of germination and root development [21]. Crude unextracted SCG hydrochars were therefore excluded from further study.

An additional soil-less petri dish assay assessed the dose-response relationship of the SCG-based substrates with the germination and early seedling growth of land cress (Barbarea verna L.) One-way analysis of variance (ANOVA) and Dunnett's post-hoc test identified the effects of each application rate relative to the control (dose rate $=0$ $\mathrm{t} / \mathrm{ha}$ ) at $p<0.05$ significance level. With the exception of $260 \mathrm{PE}$ at the highest dose rates (20 and $40 \mathrm{t} / \mathrm{ha}$ ), all primary chars and the pre-treated feedstock stunted root development relative to the control (Fig. 3). Raw SCG either depressed or had no effect on root length at dose rates of 10 and 40;5 and $20 \mathrm{t} /$ ha respectively. A statistically significant positive result was recorded only for 223 RAW (20 and $40 \mathrm{t} / \mathrm{ha}$ ) and $260 \mathrm{RAW}$ (40 t/ha), where the greatest stimulatory effect of $35 \%$ was recorded for $223 \mathrm{RAW}$ at $20 \mathrm{t} / \mathrm{ha}$. Seed germination rates (GR) were generally reduced or unchanged relative to the control (average $=75 \%$ ), except for chars from the moderate and severe HTC regimes. At the highest application rate 223 RAW improved germination by $22 \%$, whilst doses of up to $20 \mathrm{t} / \mathrm{ha}$ of $223 \mathrm{PE}$ and both 260 primary chars were stimulatory for cress seeds $(\max =56 \%$ for $260 \mathrm{PE}$ at $20 \mathrm{t} /$ ha). Results observed for 223 and 260 primary chars are the first positive indication of the potential of SCG hydrochars as horticultural amendments. Subsequently a climactic chamber trial assessing the effect of the SCG PCs on the 


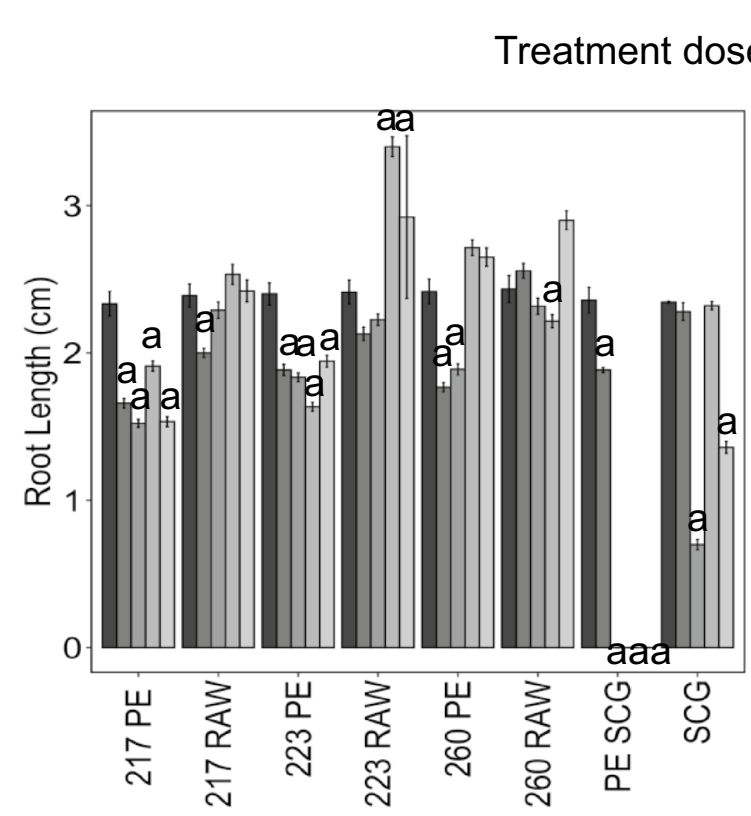

Fig. 3 Root length (left) and germination rate (right) of land cress seedlings treated with spent coffee grounds (SCG), alkali pre-treated SCG (PE SCG) and corresponding primary chars from the hydro-

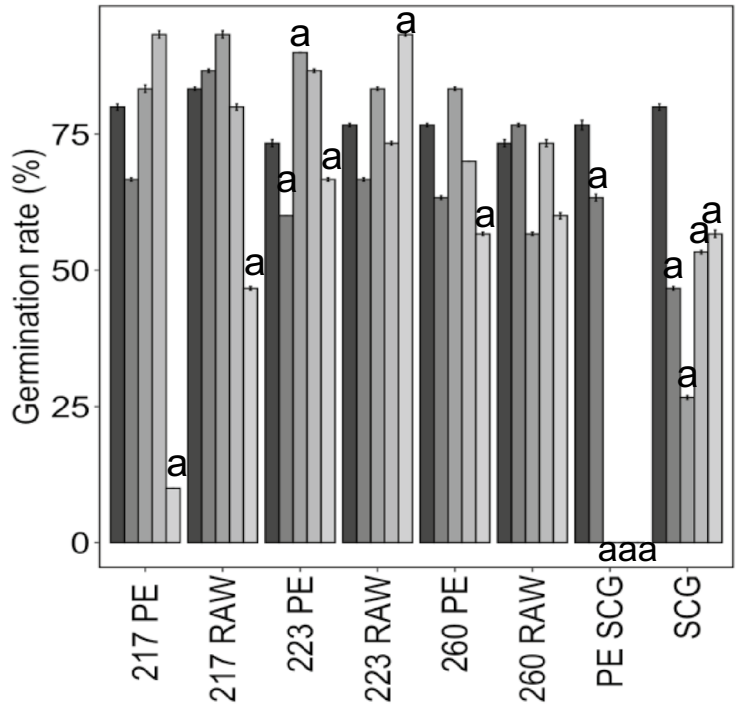

thermal carbonisation of the feedstock under three process regimes. Significantly different results from that of the group control mean $(p<0.05)$ are labelled

Table 2 Effect of primary chars from HTC of SCG (RAW PC) and alkaline pre-treated (PE PC) feedstocks on commercial topsoil chemical and physicochemical properties at $100 \mathrm{t} / \mathrm{ha}$ application rates

\begin{tabular}{|c|c|c|c|c|c|c|c|c|}
\hline Sample & $\mathrm{OM}^{1}(\%)$ & $\mathrm{pH}$ & $\mathrm{CEC}(\mathrm{meq} / 100 \mathrm{~g})^{2}$ & $\mathrm{OC}(\mathrm{ppm})^{3}$ & $\mathrm{~N}(\mathrm{ppm})$ & $\mathrm{C}: \mathrm{N}$ & $\mathrm{Ca}(\mathrm{ppm})$ & $\operatorname{Mg}(\mathrm{ppm})$ \\
\hline Topsoil (TS) & $9.4 \pm 0.5^{\mathrm{a}}$ & $7.9 \pm 0.1^{\mathrm{a}}$ & $23 \pm 0.0^{\mathrm{a}}$ & $5.5 \pm 0.3^{\mathrm{a}}$ & $0.60 \pm 0.01^{\mathrm{a}}$ & $9.14 \pm 0.46^{\mathrm{a}}$ & $3360 \pm 90^{\mathrm{a}}$ & $260 \pm 9^{b}$ \\
\hline TS + 217 RAW PC & $14.6 \pm 0.7^{b}$ & $7.9 \pm 0.1^{\mathrm{a}}$ & $20.3 \pm 0.0^{\mathrm{a}}$ & $8.5 \pm 0.4^{\mathrm{b}}$ & $0.8 \pm 0.01^{\mathrm{b}}$ & $10.63 \pm 0.53^{\mathrm{ab}}$ & $3000 \pm 80^{\mathrm{a}}$ & $233 \pm 8^{b}$ \\
\hline $\mathrm{TS}+217 \mathrm{PE} \mathrm{PC}$ & $13.8 \pm 0.7^{b}$ & $7.9 \pm 0.1^{\mathrm{a}}$ & $20.3 \pm 0.0^{\mathrm{a}}$ & $8 \pm 0.4^{\mathrm{b}}$ & $0.65 \pm 0.01^{\mathrm{b}}$ & $12.31 \pm 0.62^{\mathrm{b}}$ & $2974 \pm 79^{\mathrm{a}}$ & $233 \pm 8^{b}$ \\
\hline $\mathrm{TS}+223 \mathrm{RAW} \mathrm{PC}$ & $14.6 \pm 0.7^{b}$ & $7.9 \pm 0.1^{\mathrm{a}}$ & $20 \pm 0.0^{\mathrm{a}}$ & $8.5 \pm 0.4^{\mathrm{b}}$ & $0.79 \pm 0.01^{\mathrm{b}}$ & $10.83 \pm 0.54^{\mathrm{a}}$ & $3025 \pm 81^{\mathrm{a}}$ & $224 \pm 7^{b}$ \\
\hline $\mathrm{TS}+223 \mathrm{PE} \mathrm{PC}$ & $13.6 \pm 0.7^{b}$ & $8.1 \pm 0.1^{\mathrm{a}}$ & $21.9 \pm 0.0^{\mathrm{a}}$ & $7.9 \pm 0.4^{\mathrm{b}}$ & $0.63 \pm 0.01^{\mathrm{a}}$ & $12.54 \pm 0.63^{\mathrm{b}}$ & $3277 \pm 87^{\mathrm{a}}$ & $245 \pm 8^{\mathrm{b}}$ \\
\hline $\mathrm{TS}+260 \mathrm{RAW} \mathrm{PC}$ & $14.2 \pm 0.7^{\mathrm{b}}$ & $8.1 \pm 0.1^{\mathrm{a}}$ & $19.5 \pm 0.0^{\mathrm{a}}$ & $8.3 \pm 0.4^{\mathrm{b}}$ & $0.76 \pm 0.01^{\mathrm{b}}$ & $10.99 \pm 0.55^{\mathrm{a}}$ & $2973 \pm 79^{a}$ & $214 \pm 7^{\mathrm{a}}$ \\
\hline $\mathrm{TS}+260 \mathrm{PE} \mathrm{PC}$ & $14 \pm 0.7^{\mathrm{b}}$ & $8.0 \pm 0.1^{\mathrm{a}}$ & $20.8 \pm 0.0^{\mathrm{a}}$ & $8.1 \pm 0.4^{\mathrm{b}}$ & $0.66 \pm 0.01^{\mathrm{b}}$ & $12.37 \pm 0.62^{b}$ & $3185 \pm 85^{\mathrm{a}}$ & $225 \pm 8^{b}$ \\
\hline Sample & $\mathrm{Mn}(\mathrm{ppm})$ & $\mathrm{B}(\mathrm{ppm})$ & $\mathrm{Cu}(\mathrm{ppm})$ & $\mathrm{Fe}(\mathrm{ppm})$ & $\mathrm{Zn}(\mathrm{ppm})$ & $\mathrm{P}(\mathrm{ppm})$ & $\mathrm{K}(\mathrm{ppm})$ & $\mathrm{Na}(\mathrm{ppm})$ \\
\hline Topsoil (TS) & $49 \pm 2^{b}$ & $4.87 \pm 0.5^{\mathrm{a}}$ & $3.5 \pm 0.2^{\mathrm{a}}$ & $1231 \pm 41^{\mathrm{a}}$ & $12.5 \pm 0.8^{\mathrm{a}}$ & $56 \pm 2^{\mathrm{a}}$ & $2263 \pm 75^{\mathrm{a}}$ & $620 \pm 41^{\mathrm{a}}$ \\
\hline TS + 217 RAW PC & $44 \pm 2^{\mathrm{b}}$ & $3.78 \pm 0.4^{\mathrm{a}}$ & $3 \pm 0.2^{\mathrm{a}}$ & $1253 \pm 42^{\mathrm{a}}$ & $10.8 \pm 0.7^{\mathrm{a}}$ & $54 \pm 2^{\mathrm{a}}$ & $1965 \pm 66^{\mathrm{ab}}$ & $547 \pm 36^{\mathrm{a}}$ \\
\hline $\mathrm{TS}+217 \mathrm{PE} \mathrm{PC}$ & $48 \pm 2^{\mathrm{b}}$ & $4.23 \pm 0.4^{\mathrm{a}}$ & $2.8 \pm 0.1^{\mathrm{a}}$ & $1249 \pm 42^{\mathrm{a}}$ & $11.2 \pm 0.7^{\mathrm{a}}$ & $54 \pm 2^{\mathrm{a}}$ & $1967 \pm 66^{\mathrm{ab}}$ & $566 \pm 38^{a}$ \\
\hline TS + 223 RAW PC & $44 \pm 2^{\mathrm{b}}$ & $3.89 \pm 0.4^{\mathrm{a}}$ & $3.3 \pm 0.2^{\mathrm{a}}$ & $1235 \pm 41^{\mathrm{a}}$ & $11.5 \pm 0.8^{\mathrm{a}}$ & $55 \pm 2^{\mathrm{a}}$ & $1881 \pm 63^{b}$ & $512 \pm 34^{a}$ \\
\hline $\mathrm{TS}+223 \mathrm{PE} \mathrm{PC}$ & $55 \pm 3^{\mathrm{a}}$ & $4.50 \pm 0.5^{\mathrm{a}}$ & $3.6 \pm 0.2^{\mathrm{a}}$ & $1221 \pm 41^{\mathrm{a}}$ & $11.5 \pm 0.8^{\mathrm{a}}$ & $53 \pm 2^{\mathrm{a}}$ & $2077 \pm 69^{\mathrm{ab}}$ & $562 \pm 37^{\mathrm{a}}$ \\
\hline $\mathrm{TS}+260$ RAW PC & $47 \pm 2^{\mathrm{b}}$ & $4.67 \pm 0.5^{\mathrm{a}}$ & $3 \pm 0.2^{\mathrm{a}}$ & $1228 \pm 41^{\mathrm{a}}$ & $11.2 \pm 0.7^{\mathrm{a}}$ & $53 \pm 2^{\mathrm{a}}$ & $1828 \pm 61^{\mathrm{b}}$ & $483 \pm 32^{\mathrm{a}}$ \\
\hline $\mathrm{TS}+260 \mathrm{PE} \mathrm{PC}$ & $50 \pm 2^{\mathrm{b}}$ & $4.42 \pm 0.4^{\mathrm{a}}$ & $3.1 \pm 0.2^{\mathrm{a}}$ & $1224 \pm 41^{\mathrm{a}}$ & $10.7 \pm 0.7^{\mathrm{a}}$ & $51 \pm 2^{\mathrm{a}}$ & $1929 \pm 64^{b}$ & $503 \pm 34^{\mathrm{a}}$ \\
\hline
\end{tabular}

${ }^{1}$ Organic matter $(\%)$

${ }^{2}$ Cation exchange capacity

${ }^{3}$ Organic carbon

(mean \pm sem, $n=3$ ). Different letters in each column denote statistically significant results $(p<0.05)$ identified using ANOVA and Tukey's post hoc tests

growth of Arabidopsis thaliana (Arabidopsis) in topsoil was carried out.

\section{Arabidopsis thaliana Climatic Chamber Trial}

Effect of SCG PCs on Topsoil Chemical and Physiocochemical 
Properties For the growth trial a commercially available, peat free, sandy-loam topsoil (TS, texture $=44 \%$ silt, $14 \%$ clay and $42 \%$ sand) was used to monitor hydrochar application under agriculturally relevant conditions. Arabidopsis is a widely adopted model specimen for agricultural biotechnology and is conventionally cultivated in peat-based media (PBM) in laboratory settings. Compared with peatfree media (PFM), the peat base media resulted in higher biomass accumulation, seed yield and lower susceptibility to fungal infection (Table S1, supplementary data) [38]. Yet, extraction of peat is associated with GHG emissions and destruction of natural peatland habitats. In line with the overall sustainability research arch, we explored the viability of spent coffee grounds as an amendment for peat-free media to support vegetative growth of Arabidopsis. Thus, the performance of SCG primary chars as soil ameliorants was modelled by cultivating Arabidopsis under environmentally stressed conditions.
The physicochemical and chemical properties of the topsoil control and topsoil treated with SCG primary chars at application rates of $100 \mathrm{t} / \mathrm{ha}$ are displayed in Table 2 . Organic Matter and Organic Carbon (OC) were uniformly significantly improved $(p<0.05)$ by all primary chars, with the highest numeric values obtained by the primary chars produced from the raw SCG (50\% average increase). This result corroborates with the higher fixed carbon and $\mathrm{C}$ observed in the characterisation data (Table 1). Similarly, $\mathrm{C}: \mathrm{N}$ ratios were improved significantly by the primary chars produced from the protein extracted feedstock, with the highest (12.54) obtained by topsoil amended with primary char produced at $223{ }^{\circ} \mathrm{C}(223 \mathrm{PE} \mathrm{PC})$. In terms of nutrients, SCG primary chars somewhat reduced concentrations, however significant results were only obtained for $\mathrm{K}$ and $\mathrm{Mg}$ macronutrients with topsoil including the primary char produced from raw SCG at $260^{\circ} \mathrm{C}(\mathrm{TS}=2263$ and $260 \mathrm{ppm}$; $\mathrm{TS}+260$ RAW PC $=1828$ and 214 ppm respectively). Presumably the relatively low ash content of the hydrochars (Table 1)

Table 3 Effect of primary chars from HTC of SCG (RAW PC) and alkaline pre-treated SCG (PE PC) feedstocks on Arabidopsis growth characteristics after 28 days

\begin{tabular}{|c|c|c|c|c|c|}
\hline Sample & $\begin{array}{l}\text { Biochar application } \\
\text { rate }\left(\mathrm{t} \mathrm{ha}^{-1}\right)\end{array}$ & Rosette diameter (mm) & Leaf number & Fresh weight (mg) & Dry weight (mg) \\
\hline \multirow[t]{4}{*}{217 RAW PC } & 0 & $9.33 \pm 0.88^{c}$ & $6.67 \pm 0.67^{\mathrm{ab}}$ & $18.67 \pm 4.33^{\mathrm{bc}}$ & $6.37 \pm 1.65^{\mathrm{b}}$ \\
\hline & 20 & $5.33 \pm 1.45^{\mathrm{c}}$ & $6.33 \pm 0.67^{\mathrm{ab}}$ & $15.33 \pm 2.73^{c}$ & $3.77 \pm 0.61^{\mathrm{b}}$ \\
\hline & 50 & $4.00 \pm 0.58^{\mathrm{c}}$ & $4.00 \pm 0.00^{\mathrm{b}}$ & $1.97 \pm 0.09^{c}$ & $1.73 \pm 0.63^{b}$ \\
\hline & 100 & $3.33 \pm 0.67^{c}$ & $3.67 \pm 0.88^{\mathrm{b}}$ & $3.77 \pm 1.13^{\mathrm{c}}$ & $1.20 \pm 0.50^{\mathrm{b}}$ \\
\hline \multirow[t]{4}{*}{217 PE PC } & 0 & $16.33 \pm 2.40^{\mathrm{bc}}$ & $9.67 \pm 1.20^{\mathrm{ab}}$ & $45.67 \pm 6.84^{\mathrm{bc}}$ & $4.87 \pm 2.15^{\mathrm{b}}$ \\
\hline & 20 & $4.00 \pm 0.00^{c}$ & $4.00 \pm 0.00^{\mathrm{b}}$ & $2.60 \pm 0.40^{\mathrm{c}}$ & $0.25 \pm 0.05^{\mathrm{b}}$ \\
\hline & 50 & $3.00 \pm 0.58^{\mathrm{c}}$ & $3.00 \pm 0.58^{\mathrm{b}}$ & $2.40 \pm 0.10^{\mathrm{c}}$ & $0.53 \pm 0.03^{\mathrm{b}}$ \\
\hline & 100 & $3.33 \pm 0.67^{\mathrm{c}}$ & $3.67 \pm 1.00^{\mathrm{b}}$ & $3.77 \pm 0.71^{\mathrm{c}}$ & $1.20 \pm 0.03^{\mathrm{b}}$ \\
\hline \multirow[t]{4}{*}{223 RAW PC } & 0 & $6.67 \pm 1.33^{\mathrm{c}}$ & $6.67 \pm 0.88^{\mathrm{ab}}$ & $13.33 \pm 0.67^{\mathrm{bc}}$ & $2.77 \pm 0.63^{b}$ \\
\hline & 20 & $9.00 \pm 2.65^{c}$ & $7.00 \pm 0.58^{\mathrm{ab}}$ & $10.33 \pm 1.86^{\mathrm{c}}$ & $2.87 \pm 0.43^{\mathrm{b}}$ \\
\hline & 50 & $8.33 \pm 1.63^{c}$ & $4.67 \pm 0.41^{\mathrm{b}}$ & $7.33 \pm 5.31^{\mathrm{c}}$ & $2.20 \pm 1.92^{\mathrm{b}}$ \\
\hline & 100 & $4.00 \pm 0.58^{\mathrm{c}}$ & $4.33 \pm 0.33^{\mathrm{b}}$ & $3.07 \pm 0.58^{\mathrm{c}}$ & $2.23 \pm 0.43^{\mathrm{b}}$ \\
\hline \multirow[t]{4}{*}{223 PE PC } & 0 & $7.00 \pm 2.00^{c}$ & $4.67 \pm 0.88^{\mathrm{ab}}$ & $4.67 \pm 0.88^{c}$ & $1.60 \pm 0.44^{\mathrm{b}}$ \\
\hline & 20 & $5.67 \pm 2.65^{c}$ & $4.33 \pm 0.58^{\mathrm{ab}}$ & $2.67 \pm 1.86^{\mathrm{c}}$ & $1.30 \pm 0.43^{\mathrm{b}}$ \\
\hline & 50 & $4.00 \pm 0.00^{c}$ & $4.00 \pm 0.00^{\mathrm{ab}}$ & $1.50 \pm 0.41^{\mathrm{c}}$ & $0.55 \pm 0.12^{\mathrm{b}}$ \\
\hline & 100 & $4.33 \pm 0.33^{c}$ & $4.00 \pm 0.00^{\mathrm{b}}$ & $1.57 \pm 0.23^{\mathrm{c}}$ & $1.03 \pm 0.18^{\mathrm{b}}$ \\
\hline \multirow[t]{4}{*}{260 RAW PC } & 0 & $5.67 \pm 0.33^{c}$ & $5.67 \pm 0.88^{\mathrm{ab}}$ & $16.00 \pm 2.08^{c}$ & $9.40 \pm 0.62^{\mathrm{b}}$ \\
\hline & 20 & $12.33 \pm 3.53^{\mathrm{bc}}$ & $7.00 \pm 1.53^{\mathrm{ab}}$ & $28.00 \pm 5.51^{\mathrm{bc}}$ & $13.57 \pm 2.50^{\mathrm{b}}$ \\
\hline & 50 & $13.33 \pm 1.45^{\mathrm{bc}}$ & $10.00 \pm 2.52^{\mathrm{ab}}$ & $91.00 \pm 73.02^{\mathrm{bc}}$ & $17.97 \pm 12.22^{\mathrm{ab}}$ \\
\hline & 100 & $50.00 \pm 2.65^{\mathrm{a}}$ & $12.67 \pm 0.88^{\mathrm{a}}$ & $294.00 \pm 73.9^{\mathrm{a}}$ & $42.63 \pm 12.81^{\mathrm{a}}$ \\
\hline \multirow[t]{4}{*}{260 PE PC } & 0 & $8.00 \pm 0.00^{\mathrm{c}}$ & $6.67 \pm 0.67^{\mathrm{ab}}$ & $10.33 \pm 4.33^{c}$ & $3.50 \pm 1.23^{\mathrm{b}}$ \\
\hline & 20 & $9.47 \pm 4.53^{c}$ & $6.00 \pm 0.58^{\mathrm{ab}}$ & $11.67 \pm 4.91^{\mathrm{c}}$ & $2.97 \pm 0.50^{\mathrm{b}}$ \\
\hline & 50 & $14.67 \pm 6.33^{\mathrm{bc}}$ & $8.67 \pm 3.18^{\mathrm{ab}}$ & $30.00 \pm 22.03^{\mathrm{bc}}$ & $7.83 \pm 5.84^{b}$ \\
\hline & 100 & $50.50 \pm 11.50^{\mathrm{ab}}$ & $14.50 \pm 2.50^{\mathrm{ab}}$ & $292.00 \pm 118.00^{\mathrm{ab}}$ & $37.65 \pm 9.35^{\mathrm{ab}}$ \\
\hline
\end{tabular}

$($ mean \pm sem, $n=3$ )

Different letters in each column denote statistically significant results $(p<0.05)$ identified using ANOVA and Tukey's post hoc tests 


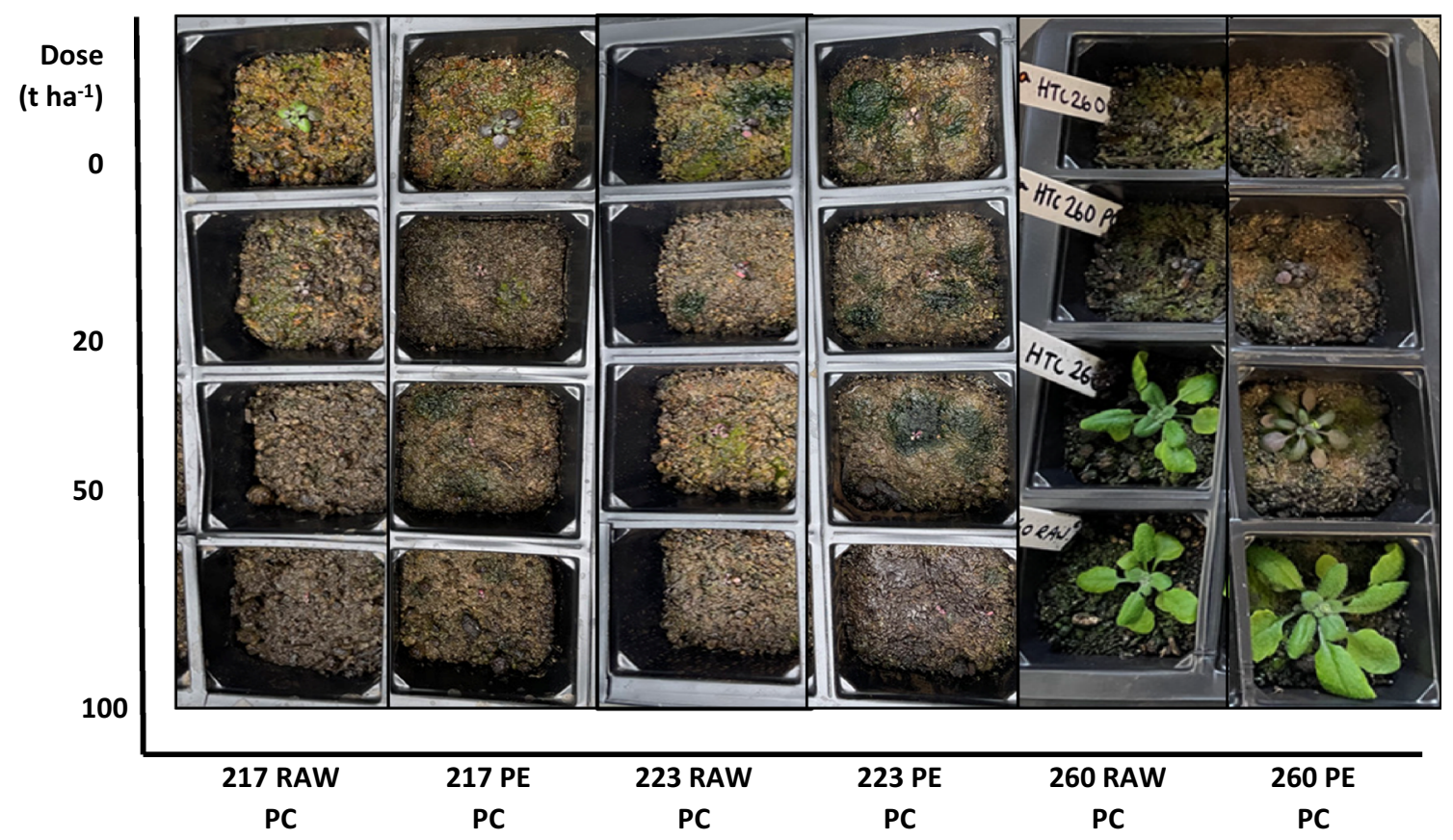

Fig. 4 Arabidopsis rosettes 28 days after planting in sandy-loam topsoil treated with primary chars from the hydrothermal carbonisation of spent coffee grounds (RAW PC) and alkali pre-treated SCG (PE

impacted mineral content, where incorporation into topsoil reduced nutrients proportional to weight percentage.

Compared with a commercially available peat-based media (Figure S2, supplementary data), the topsoil used here had a slight alkaline $\mathrm{pH}(7.9 ; \mathrm{PBM}=5.6)$ that was unaffected by primary char application. $\mathrm{Ca}, \mathrm{Fe}, \mathrm{K}$ and $\mathrm{Na}$ are present up to 8-fold higher in concentration in the topsoil versus the peat-based media, whilst $\mathrm{Mg}$ was 4-fold higher in the commercial peat-based media. The optimal performance of Arabidopsis in peat-based media (S2, supplementary data) could be influenced by nutrition: root system architecture is modulated by mineral availability, where deficiencies promote the development of longer systems [39]. $\mathrm{N}$ also impacts morphological traits and developmental phase transitions of Arabidopsis ecotypes [40, 41]. The peat-based media's sandy texture (98\%) and lower $\mathrm{pH}$ may also impact water holding capacity, nutrient mobility and uptake in a manner supportive of plant development [42].

\section{Effect of SCG Primary Char on Arabidopsis Rosette} Growth Growth measurements (rosette diameter, leaf number, fresh and dry weight) were collected 28 days after planting Arabidopsis in topsoil treated with SCG primary char at application rates of 0 (control), 20, 50 and $100 \mathrm{t} / \mathrm{ha}$ (Table 3 , Fig. 4). Notably, the primary chars produced at $260{ }^{\circ} \mathrm{C}$ from both the raw and protein extracted SCGs enhanced plant growth at each application rate: no toxic effects were
PC) under different regimes. Primary chars were applied to soils at different application rates $(0,20,50$ and $100 \mathrm{t} / \mathrm{ha})$

observed across doses. However, whilst significant results $(p<0.05)$ were observed at $100 \mathrm{t} / \mathrm{ha}$ for both 260 primary chars, the primary char produced from the protein extracted feedstock (260 PE PC) yielded the biggest increases (531, 118,2726 and $976 \%$ for rosette diameter, leaf number, fresh and dry weight respectively) relative to the control.

A greater stimulatory effect was recorded for the primary char produced from raw SCG at $260{ }^{\circ} \mathrm{C}(260 \mathrm{RAW}$ PC) at lower dose rates, which also gave highest dry mass at $100 \mathrm{t} / \mathrm{ha}(42.63 \mathrm{mg})$. In terms of phenotypic development, the rosette diameter and leaf number indicate the growth stage attained by the wild type Col-0 Arabidopsis during the trial. At the highest dose, both primary chars produced at $260^{\circ} \mathrm{C}$ cultivated rosettes with typical phenotypical traits for 28 days (average diameter and leaf number $=50.3 \mathrm{~mm}$ and 13.58 respectively), unlike all other measured settings whose data suggests stunted plant development [43]. This data highlights the stressed conditions of the study as well as the ability of the high temperature chars to support normal plant development at higher doses. Visual observations of orange hued rings on the topsoil surface and poor plant growth, as shown in Fig. 4, suggest fungal contamination, which has been reported for other peat free medias and was not observed for Arabidopsis cultivated in peat based media (S2, supplementary data) [38]. Primary chars produced under milder HTC conditions mostly inhibited Arabidopsis relative to the control and yields decreased conversely with increasing application rate. 
The performance of both the primary chars produced at $260{ }^{\circ} \mathrm{C}$ in this study is exemplary for SCG-based soil amendments and contrary to the established consensus on their phytotoxic and inhibitory activities. Indeed, a recent exploration by Cervera-Mata et al. reported the inhibition of lettuce grown in the presence of SCG hydrochars (1 and 2.5\%) washed with deionised water in a post-treatment. These chars were produced under milder HTC settings $(\mathrm{T}=175$ and $185^{\circ} \mathrm{C}, \mathrm{t}=1 \mathrm{~h}$ ), and results corroborated with those obtained for 217 PE and 217 RAW PCs in this study. Despite stunted growth, crops exhibited enhanced mineral and polyphenolic content, mirroring previous investigations [18].

As previously noted, phytotoxicity is generally attributed to the presence of polyphenols, which are likely to accumulate in the char at lower reaction temperatures. This can be inferred by several temperature-dependent phenomena that result in solubilisation and decomposition of phenolic and alkaloid constituents in the HTC liquid phase. Hydroxycinnamic acids are an abundant class of SCG polyphenol, of which chlorogenic acids (esters of caffeic and quinic acids) are present up to $3 \%$ in SCG as free-CGA or incorporated with melanoidins [44, 45]. Crystalline CGA melts at $206-207^{\circ} \mathrm{C}$ and hydrolysis of CGA isomer 3-O-caffeoyl quinic acid (3-CQA) occurs above $147{ }^{\circ} \mathrm{C}$ [31]. Therefore, migration of CGA into the aqueous phase likely concurs with the disintegration of structural hemicellulose and cellulose constituents [46]. Presumably the reaction severity of HTC 260 afforded greater decomposition of the phenolic fraction of SCG and caffeine, thereby reducing the phytotoxicity of primary chars produced at $260^{\circ} \mathrm{C}$. This was demonstrated by Arauzo et al. in ultrasound assisted extracts of SCG hydrochars generated at $200{ }^{\circ} \mathrm{C}, 230{ }^{\circ} \mathrm{C}$ and $260{ }^{\circ} \mathrm{C}$ : total phenolic content of the hydrochars decreased with reaction temperature (from 4.95 to $1.95 \mathrm{mg} \mathrm{GAE} / \mathrm{g} \mathrm{SCG}$ at 200 and $260{ }^{\circ} \mathrm{C}$ respectively). Changing extraction solvents to methanol or methanol: water $(50: 50 \mathrm{v} / \mathrm{v})$ increased retention of total phenolic content in liquid extracts of the hydrochars due to increased solubility of alkaloids and polyphenols in organic solvents [47]. This likely contributed to the discrepancy between the results of this study (SCG PCs extracted using acetone: methanol $(50: 50, \mathrm{v} / \mathrm{v}))$ and those

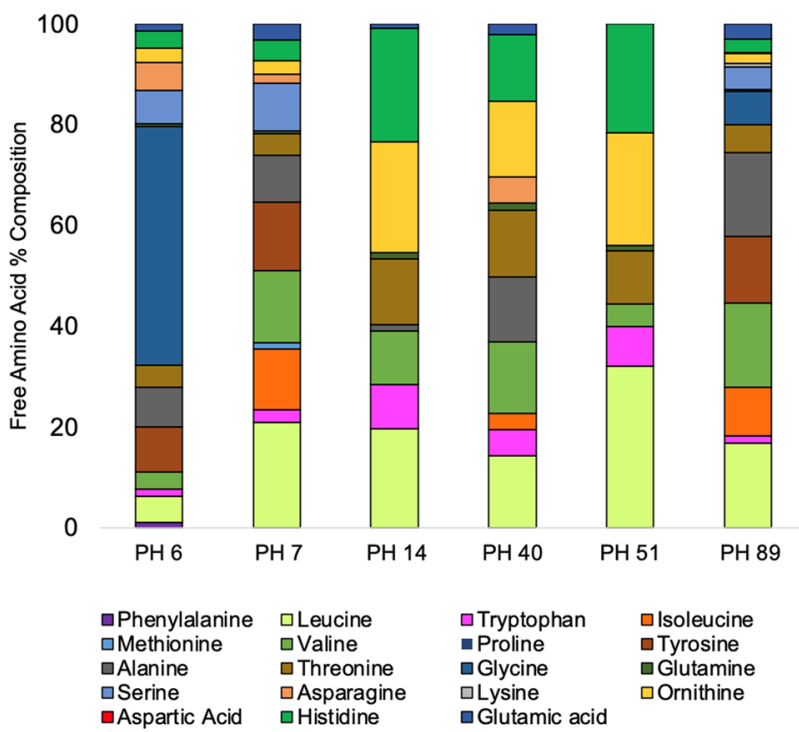

Fig. 5 Percentage composition of free amino acids in spent coffee ground enzymatic protein hydrolysates (SCG PH)

reported by Cervera-Mata et al. (SCG hydrochars washed with deionised water) as organic extraction of secondary chars further reduced the phenolic content of the solids [18]. A similar trend in the biocharization of SCG was also reported in a related study by Cervera-Mata et al. where increasing destruction of phenolic content with temperature was attributed to removal of phytotoxicity and higher biomass yields [17].

As a nitrogen containing lignocellulosic feedstock, $\mathrm{N}$ is incorporated into SCG hydrochars by reactions between nascent amino acids and phenolic fragments (Mannich reactions) or carbohydrates (Malliard reactions) [48]. The data of Table 1 shows an increase of $\mathrm{N}$ across regimes for both feedstock types, suggesting the high temperature promotion of these reactions with increasing liquid phase concentration of phenolic and carbohydrate fragments. This may account for the poorer performance of primary chars from protein extracts vs those produced from the raw feedstock: the alkaline extraction of proteins prior to HTC consequently
Table 4 Enzymes used in protein hydrolysis of spent coffee grounds and free amino acid content of SCG protein hydolysates

\begin{tabular}{lllcc}
\hline Protein Hydrolysate & Enzyme & Organism & $\begin{array}{c}\text { Degree of } \\
\text { hydrolysis }\end{array}$ & $\begin{array}{c}\text { Free amino } \\
\text { acids (mM) }\end{array}$ \\
\hline SCG PH 6 & P6 & Bacillus licheniformis & 23.6 & 2.65 \\
SCG PH 7 & P7 & Bacillus amyloliquefaciens & 9.22 & 1.92 \\
SCG PH 14 & P14 & Geobascillus sp. & 11.9 & 0.22 \\
SCG PH 40 & P40 & Bacillus subtilis & 29.3 & 0.41 \\
SCG PH 51 & P51 & Aspergillus oryzae & - & 0.23 \\
SCG PH 89 & P89 & Bacillus Subtilis & 11.9 & 3.02 \\
\hline
\end{tabular}

- Not determined for extraction under acidic conditions 
reduced formation and altered the composition of the aromatic heterocyclic network of the solid. Thus, promotion of the condensation and polymerisation of phenolic fragments may be responsible for the increased phytotoxic qualities of primary chars from protein extracts, as chars with a higher proportion of polyphenolic allelochemicals were presumably formed. However, this effect requires further investigation, particularly considering the outstanding performance of 260 PE PC (vs 260 RAW PC) at 100 t/ha.

\section{SCG Protein Hydrolysates as Biostimulants}

Protein hydrolysates from spent coffee grounds (SCG PH) were obtained following a screening of enzymes from several organisms. SCG PH were subsequently evaluated for their biostimulant potential according to a method reported by Saporta et al. [25]. Plant metabolism is influenced by the activities of microbial populations in the rhizosphere as well as that of its own signal transduction pathways and regulator molecules [49]. Therefore an initial inoculation with S. cerevisiae was conducted to assess SCG PH impact on microbial growth. SCG PH were then evaluated for their effect on the germination rate of Arabidopsis in solid medium and auxinlike activity using land cress (Barbarea verna $\mathrm{L}$ ).

\section{Degree of Hydrolysis (DH) and Free L-Amino Acid Content of SCG-Protein Hydrolysates (SCG PH)}

A range of microorganisms were used in enzymatic extractions of SCG giving differing degrees of hydrolysis (DH) and free L-amino acid content (Table 4). Percentage composition of amino acids in the protein hydrolysates are displayed in Fig. 5. The degree of hydrolysis, the measure of cleaved peptide bonds within the protein hydrolysate was determined using the $\mathrm{pH}$ Stat method for extractions under neutral or alkaline conditions. The diverse proteolytic activity of Bacillus subtilus was evident in the highest and last but one DH (29.3 and 11.9\% for SCG PH 40 and SCG PH 89 respectively), which corresponded to an inverse trend in the proportions of free amino acids $(0.41 \mathrm{mM}$ and $3.02 \mathrm{mM}$ respectively, Table 4). This, along with the varied amino acid composition of SCG PH highlights the specificity of strains within and across microbial species. Thus, screenings are imperative to selectively retain protein hydrolysates with functional activities e.g. bioactive peptides.

For the stimulation of plant processes, SCG PH contain amino acids alanine, glycine, glutamine, lysine, valine and leucine, that are implicated in the improvement of physiological traits under normal conditions and abiotic stress [13, 50]. L-glycine (present in SCG PH 6 and 89 only, at 47.3 and $6.50 \%$ of total free amino acids respectively) is associated with increased crop quality and yield and is an integral component in the industrial production of aminochelate

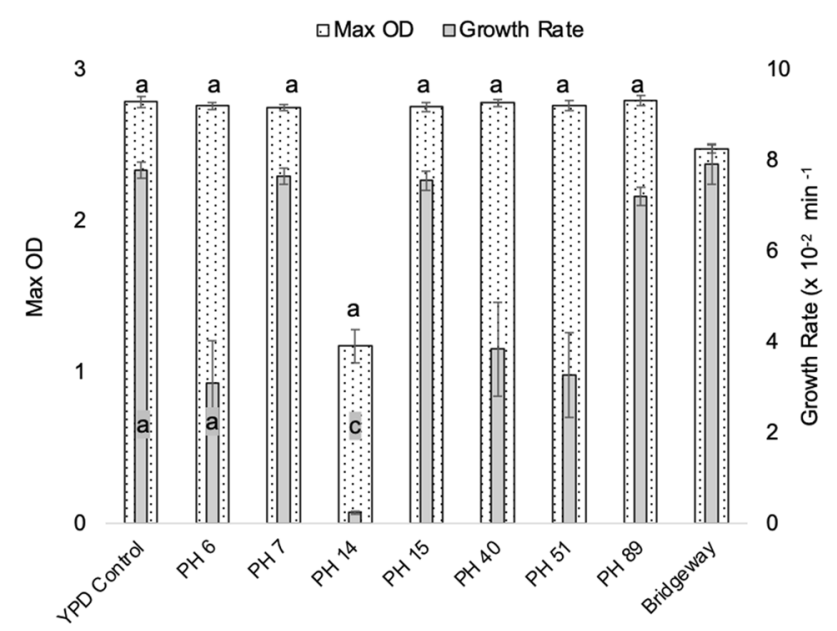

Fig. 6 Growth rate and maximum optical density data for $S$. cerevisiae inoculated with yeast peptone dextrose (YPD) media only or $5 \%$ enzymatic spent coffee ground protein hydrolysates (SCG $\mathrm{PH}$ ) or Bridgeway biostimulant solutions in YPD. Significant differences between treatment means $(p<0.05)$ are expressed by different letters

fertilizers [51-53]. However it must be noted that proline, which has been extensively investigated for osmotic protection against abiotic stress, was not detected in the SCG PH [54].

\section{Evaluation of the Effect of SCG PH on the Growth of S. cerevisiae}

SCG PH and Bridgeway were initially inoculated with $S$. cerevisae in petri-dish drop-tests on a solid yeast, peptone, dextrose (YPD) agar medium, to determine the concentration at which growth was inhibited (figure S3, S4 supplementary data). No toxicity was measured for aqueous SCG $\mathrm{PH}$ solutions in the tested concentration range $(98-5 \%$ vol SCG PH). Subsequently, S. cerevisiae was cultured in liquid YPD media with 5\% vol SCG PH or commercial biostimulant (Bridgeway) over 4 days and compared with a $100 \%$ YPD only media as the control. Monitoring biomass in liquid media allowed for the effects of the biostimulants on the exponential growth phase of the yeast to be quantitated, improving upon the qualitative observations of (mostly stationary phase) colonies in the preliminary drop tests [25]. The growth rates derived from $\log (\mathrm{OD})$ growth curves (supporting information) and max $\mathrm{OD}_{600 \mathrm{~nm}}$ are given in Fig. 6 . One-way ANOVA followed by Games-Howell post-hoc test at $p<0.05$ significance level identified SCG PH 6, 14 and 51 as significantly inhibitory with respect to the growth rates of YPD media control and other PH. SCG PH 14 had the poorest performance for biomass accumulation as both growth rate and max OD were 33-fold slower and 2.4- fold lower than the YPD control $\left(0.23\right.$ vs $7.77 \times 10^{-2} / \mathrm{min}$ and 1.17 vs 2.79 respectively, Fig. 6). Max OD measured for 
commercial biostimulant Bridgeway (2.47) was the other significant deviation $(p<0.05)$ observed.

The slower growth rates of S. cerevisiae in SCG PH 14, 40 and 51 may be linked to lower free amino acid concentrations (Table 4) as well as the composition. Yeasts will use amino acids as carbon and nitrogen sources, for amino acid and protein biosynthesis and conversion into other metabolites. Therefore, lower concentrations reduce rate of nitrogen uptake for metabolism, thus impacting growth rate. Amino acids are classed by their preferential uptake by yeast strains, where glutamine, glutamic acid, asparagine, serine are selectively internalised over leucine, methionine and tryptophan, for example, and promote faster generation times [55]. Of the preferred, intermediate and non-preferred classes for the S. cerevisiae strain, non-preferred amino acids of SCG PH 14, 50 and 51 constitute $59 \%, 47 \%$ and $68 \%$ of the whole respectively, which may also have contributed to slower growth. Biomass accumulation levelled out with respect to the max OD of the control for SCG PH 40 and 51, indicating eventual adaptation to nitrogen source [56]. Yet SCG PH 14 remained deleterious to yeast, suggesting other sources of toxicity. For SCG PH 6, glycine was the major amino acid component at $47 \%$, however, reduced uptake of glycine has been demonstrated for S. cerevisiae in amino acid rich media apparently due to the ability of threonine aldolase Gly $1 \mathrm{p}$ to synthesise glycine intracellularly [57]. This may explain the slower growth rates observed for SCG PH 6, as the highest proportion of an underutilised amino acid was present.
Evaluation of the Effect of SCG PH on Arabidopsis thaliana Germination Under Normal and Cold Conditions

SCG PH were tested for biostimulant effect during the germination of Arabidopsis thaliana under normal and cold stressed conditions $\left(25^{\circ} \mathrm{C}\right.$ and $10^{\circ} \mathrm{C}$ respectively). Arabidopsis seeds were placed in a solid nutrient agar medium containing either 1\% SCG PH or Bridgeway, or neither (control) and allowed to germinate in the dark for 9 days under normal conditions and 13 days in the cold trial, after which the number of expanded cotyledons were recorded. Unlike in the yeast trial, SCG PH 6 outperformed the control in both trials with 139 and $141 \%$ increase in expanded cotyledons under normal and cold conditions respectively (statistical significance $(p<0.05)$ under normal conditions (Fig. 7). SCG PH 14 and 89 adversely affected germination under normal conditions whilst all SCG PH treatments were indistinguishable from the control in the cold trial. Interestingly, despite the low dose used in the study (1\% $\mathrm{v} / \mathrm{v})$, Bridgeway was deleterious to seed germination under both conditions. The discrepancy between results from the S. cerevisiae and Arabidopsis trials suggests the mode of action is not conserved between microorganism and plant.

Arabidopsis germination results were complemented by determination of the auxin-like activity of the SCG PH. Auxins are phytohormones that regulate factors in plant development such as embryonic development, root and stem tropisms, cell division, elongation and flower formation [58]. Dose-response relationships are well-established for auxins, where lower concentrations stimulate growth of plant organs and high doses are deleterious to growth [59]. Auxin-like activity of SCG PH was determined through treatment of land cress seeds with protein
Fig. 7 Effect of enzymatic spent coffee ground protein hydrolysates (SCG PH) and commercial biostimulant Bridgeway on the number of Arabidopsis thaliana seeds with expanded cotyledons under normal and cold germination conditions. Unlabelled bars are significantly $(p<0.05)$ different from control mean

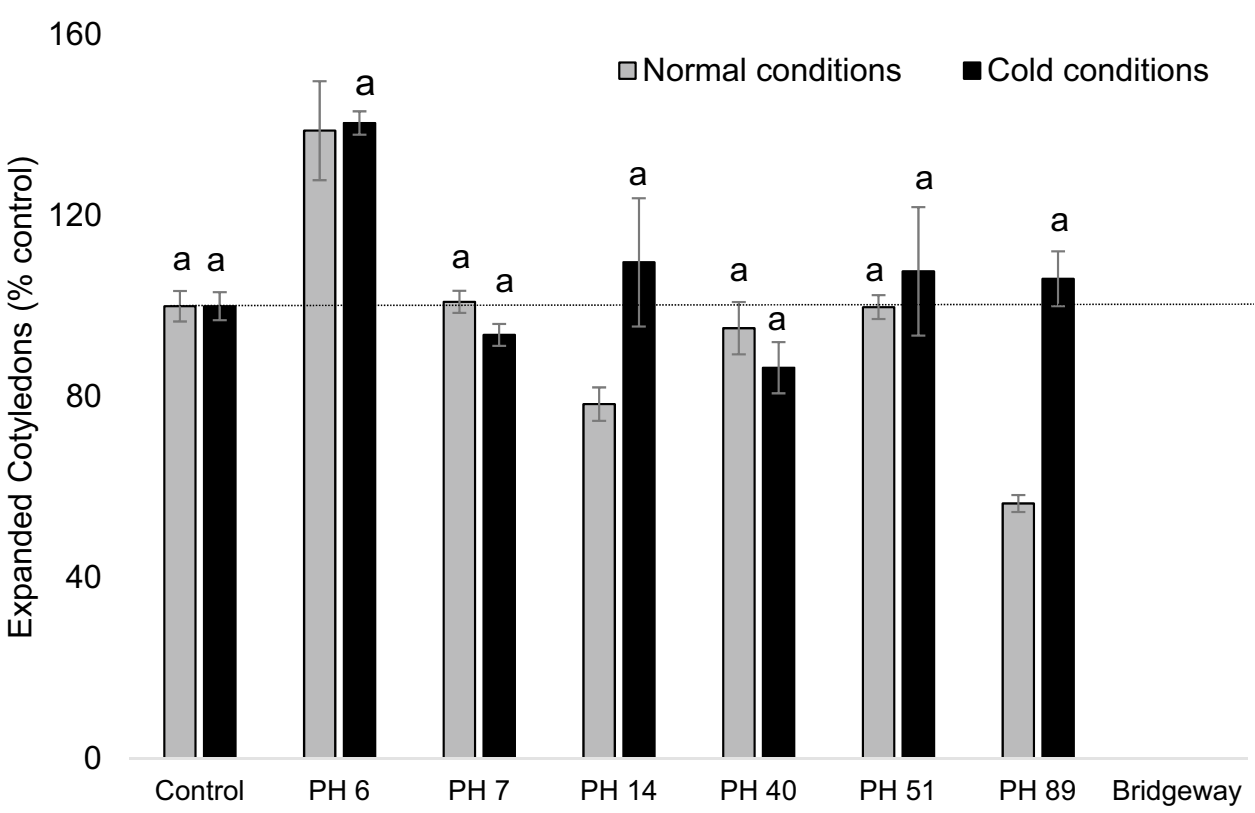


Table 5 Auxin-like activity of indole 3-acetic acid (IAA) and enzymatic spent coffee ground protein hydrolysates (SCG PH) and commercial biostimulant 'Bridgeway' on the root length of land cress

\begin{tabular}{|c|c|c|}
\hline Treatment & Concentration (ppm) & $\begin{array}{l}\text { Root length } \\
\text { decrease } \\
(\%)\end{array}$ \\
\hline \multirow[t]{5}{*}{ IAA } & 20 & $98.5^{\mathrm{ijk}}$ \\
\hline & 10 & $98.2^{\text {hij }}$ \\
\hline & 1 & $96.1^{\text {fgh }}$ \\
\hline & 0.1 & $94.1^{\text {bcde }}$ \\
\hline & 0.01 & $93.8^{\mathrm{abcd}}$ \\
\hline \multirow[t]{3}{*}{ SCG PH 6} & 127 & $98.2^{\text {fghik }}$ \\
\hline & 12.7 & $92.5^{\mathrm{abc}}$ \\
\hline & 1.27 & $90.7^{\mathrm{a}}$ \\
\hline \multirow[t]{3}{*}{ SCG PH 7} & 132 & $99.1^{\mathrm{jk}}$ \\
\hline & 13.2 & $94.7^{\text {cdef }}$ \\
\hline & 1.32 & $94.0^{\text {bcde }}$ \\
\hline \multirow[t]{3}{*}{ SCG PH 14} & 254 & $100^{\mathrm{k}}$ \\
\hline & 25.4 & $96.6^{\text {fghi }}$ \\
\hline & 2.54 & $94.2^{\text {cdef }}$ \\
\hline \multirow[t]{3}{*}{ SCG PH 40} & 53.3 & $100^{\mathrm{k}}$ \\
\hline & 5.33 & $96.0^{\mathrm{fgh}}$ \\
\hline & 0.53 & $96.2^{\text {fgh }}$ \\
\hline \multirow[t]{3}{*}{ SCG PH 51} & 127 & $92.4^{\mathrm{ab}}$ \\
\hline & 12.7 & $93.9^{\mathrm{abcd}}$ \\
\hline & 1.27 & $93.1^{\text {abcde }}$ \\
\hline \multirow[t]{3}{*}{ SCG PH 89} & 105 & $100^{\mathrm{k}}$ \\
\hline & 10.5 & $95.4^{\text {defg }}$ \\
\hline & 1.05 & $95.6^{\mathrm{efg}}$ \\
\hline \multirow[t]{3}{*}{ Bridgeway } & 0.42 & $100^{\mathrm{k}}$ \\
\hline & 0.04 & $100^{\mathrm{k}}$ \\
\hline & 0.004 & $93.4^{\text {bcde }}$ \\
\hline
\end{tabular}

Values (mean $\pm \operatorname{sem}, \mathrm{n}=3$ ) are given as percentage of root length decrease relative to the untreated control

ANOVA and Tukey post-hoc tests determined significant differences between treatment means $(p<0.05)$, expressed by different superscript letters

hydrolysates at 3 serial dilutions according to the Audus test. Root lengths were measured after $48 \mathrm{~h}$ and auxinlike activity was assessed in terms of indole-3-acetic acid (IAA) auxin standard, with respect to the untreated control (Table 5).

Root length decrease was significantly $(p<0.05)$ influenced by treatment type and dose, with SCG PH 6 and 14 exerting a strong auxin-like effect on the cress roots: root length decreased monotonically with concentration. Moderate IAA-like activity was also displayed by Bridgeway and SCG PH 7 whilst a weaker response was seen for SCG PH 40 and 89. Despite inhibiting root length, a dose-response relationship could not be established for SCG PH 51. The auxin-like behaviour of SCG PH and Bridgeway is in line with other enzymatic protein hydrolysates that contain tryptophan, which is the precursor for the biosynthesis of IAA by plants [15]. Whilst no direct correlation with tryptophan concentration and IAA-like activity can be made at this stage it is interesting to note that SCG PH 51 had the lowest concentration $(0.01 \mathrm{mM})$. However, peptides within the protein hydrolysates may also have influenced IAA-like activity, as recently reported for Arabidopsis, where CEP5 peptide signalling stabilised auxin/IAA transcriptional repressors [60].

\section{Conclusion}

In this study two major products from an SCG biorefinery were tested as possible soil amendments and biostimulants. Overall, the process products from SCG were found to be supportive of plant growth. Primary chars from the hydrothermal carbonisation (HTC) of spent coffee grounds $(\mathrm{T}=260, \mathrm{t}=4.5 \mathrm{~h})$ and alkali pre-treated $\mathrm{SCG}$ increased Arabidopsis thaliana rosette diameter, leaf number fresh and dry weight relative to the untreated control $(531,118$, 2726 and $976 \%$ respectively), when applied to topsoil at 100 t/ha. Topsoil organic carbon matter and C:N ratio was also improved by primary char application. Biostimulant activity of enzymatic protein hydrolysates was observed through increase of expanded Arabidopsis cotyledons relative to the control (SCG PH 6) and auxin-like activity on land-cress. These results are encouraging for product development of SCG based horticultural amendments, with the following findings arising from this study: post-treatments of SCG hydrochars are necessary to overcome the deleterious effects of SCG's phytotoxic aromatic components; screening of enzymes for generation of SCG protein hydrolysates is required to preferentially obtain formulations that are supportive of plant growth. An integrated approach to process design is therefore recommended for the efficient utilisation of SCG, due to its composite physicochemical and chemical properties.

Supplementary Information The online version contains supplementary material available at https://doi.org/10.1007/s12649-022-01697-x.

Acknowledgements The authors would like to thank Dr Luca Longanesi for his help with the yeast fermentation and Dr Shaun Reeksting of the Material and Chemical Characterisation Facility $\left(\mathrm{MC}^{2}\right)$ at University of Bath (https://doi.org/10.15125/mx6j-3r54) for his technical support and guidance in this work.

Funding The authors would like to thank bio-bean for their financial assistance.

Data Availability All data is freely available by contacting the corresponding author.

Code Availability N/A. 


\section{Declarations}

Conflict of interest The authors have no conflict of interest.

Open Access This article is licensed under a Creative Commons Attribution 4.0 International License, which permits use, sharing, adaptation, distribution and reproduction in any medium or format, as long as you give appropriate credit to the original author(s) and the source, provide a link to the Creative Commons licence, and indicate if changes were made. The images or other third party material in this article are included in the article's Creative Commons licence, unless indicated otherwise in a credit line to the material. If material is not included in the article's Creative Commons licence and your intended use is not permitted by statutory regulation or exceeds the permitted use, you will need to obtain permission directly from the copyright holder. To view a copy of this licence, visit http://creativecommons.org/licenses/by/4.0/.

\section{References}

1. Zhang, Z., Zhu, Z., Shen, B., Liu, L.: Insights into biochar and hydrochar production and applications: a review. Energy 171, 581-598 (2019)

2. Kalderis, D., Papameletiou, G., Kayan, B.: Assessment of orange peel hydrochar as a soil amendment: impact on clay soil physical properties and potential phytotoxicity. Waste Biomass Valoriz. 10, 3471-3484 (2019)

3. Busch, D., Stark, A., Kammann, C.I., Glaser, B.: Genotoxic and phytotoxic risk assessment of fresh and treated hydrochar from hydrothermal carbonization compared to biochar from pyrolysis. Ecotoxicol. Environ. Saf. 97, 59-66 (2013)

4. Hitzl, M., Mendez, A., Owsianiak, M., Renz, M.: Making hydrochar suitable for agricultural soil: a thermal treatment to remove organic phytotoxic compounds. J. Environ. Chem. Eng. 6, 70297034 (2018)

5. Biederman, L.A., Harpole, W.S.: Biochar and its effects on plant productivity and nutrient cycling: a meta-analysis. GCB Bioenergy 5, 202-214 (2013)

6. Torabian, S., Farhangi-Abriz, S., Alaee, T.: Hydrochar mitigates salt toxicity and oxidative stress in maize plants. Arch Agronomy Soil Sci. 67, 1104-1118 (2021)

7. Mau, V., Arye, G., Gross, A.: Poultry litter hydrochar as an amendment for sandy soils. J. Environ Manag 271, 110959 (2020)

8. Malghani, S., Jüschke, E., Baumert, J., Thuille, A., Antonietti, M., Trumbore, S., Gleixner, G.: Carbon sequestration potential of hydrothermal carbonization char (hydrochar) in two contrasting soils; results of a 1-year field study. Biol. Fertil. Soils 51, 123-134 (2015)

9. Windeatt, J.H., Ross, A.B., Williams, P.T., Forster, P.M., Nahil, M.A., Singh, S.: Characteristics of biochars from crop residues: potential for carbon sequestration and soil amendment. J. Environ. Manage. 146, 189-197 (2014)

10. du Jardin, P.: Plant biostimulants: definition, concept, main categories and regulation. Sci. Hortic. 196, 3-14 (2015)

11. M. Ricci, L. Tilbury, B. Daridon, K. Sukalac, General principles to justify plant biostimulant claims. Front. Plant Sci. 10 (2019).

12. A.C.F. de Vasconcelos, L.H.G. Chaves, Biostimulants and their role in improving plant growth under abiotic stresses. Biostimulants Plant Sci 1-14.

13. Colla, G., Nardi, S., Cardarelli, M., Ertani, A., Lucini, L., Canaguier, R., Rouphael, Y.: Protein hydrolysates as biostimulants in horticulture. Sci. Hortic. 196, 28-38 (2015)
14. Carillo, P., Colla, G., Fusco, G.M., Dell'Aversana, E., El-Nakhel, C., Giordano, M., Pannico, A., Cozzolino, E., Mori, M., Reynaud, H., Kyriacou, M.C., Cardarelli, M., Rouphael, Y.: Morphological and physiological responses induced by protein hydrolysate-based biostimulant and nitrogen rates in greenhouse spinach. Agronomy 9, 450 (2019)

15. G. Colla, Y. Rouphael, R. Canaguier, E. Svecova, M. Cardarelli, Biostimulant action of a plant-derived protein hydrolysate produced through enzymatic hydrolysis. Front Plant Sci. 5 (2014).

16. Hardgrove, S.J., Livesley, S.J.: Applying spent coffee grounds directly to urban agriculture soils greatly reduces plant growth. Urban For Urban Green 18, 1-8 (2016)

17. Cervera-Mata, A., Navarro-Alarcón, M., Rufián-Henares, J.Á., Pastoriza, S., Montilla-Gómez, J., Delgado, G.: Phytotoxicity and chelating capacity of spent coffee grounds: two contrasting faces in its use as soil organic amendment. Sci. Total Environ. 717, 137247 (2020)

18. Cervera-Mata, A., Lara, L., Fernández-Arteaga, A., Ángel RufiánHenares, J., Delgado, G.: Washed hydrochar from spent coffee grounds: A second generation of coffee residues. Evaluation as organic amendment. Waste Manag. 120, 322-329 (2021)

19. J. Massaya, K.H. Chan, B. Mills-Lamptey, C.J. Chuck, Developing a biorefinery from spent coffee grounds using subcritical water and hydrothermal carbonization. Biomass Convers. Biorefinery (2021)

20. Massaya, J., Pickens, G., Mills-Lamptey, B., Chuck, C.J.: Enhanced hydrothermal carbonization of spent coffee grounds for the efficient production of solid fuel with lower nitrogen content. Energy Fuels 35, 9462-9473 (2021)

21. Lucian, M., Volpe, M., Gao, L., Piro, G., Goldfarb, J.L., Fiori, L.: Impact of hydrothermal carbonization conditions on the formation of hydrochars and secondary chars from the organic fraction of municipal solid waste. Fuel 233, 257-268 (2018)

22. J. Adler-Nissen, Enzymic hydrolysis of food proteins, Elsevier Applied Science Publishers, 1986.

23. Steinhardt, J., Beychok, S.: Chapter 8 - Interaction of Proteins with Hydrogen Ions and Other Small Ions and Molecules. In: Neurath, H. (ed.) The Proteins Composition, pp. 139-304. Structure, and Function (Second Edition), Academic Press (1964)

24. Aspevik, T., Egede-Nissen, H., Oterhals, Ĺ: A systematic approach to the comparison of cost efficiency of endopeptidases for the hydrolysis of atlantic salmon (Salmo salar) by-products. Food Technol. Biotechnol. 54, 421-431 (2016)

25. Saporta, R., Bou, C., Frías, V., Mulet, J.M.: A method for a fast evaluation of the biostimulant potential of different natural extracts for promoting growth or tolerance against abiotic stress. Agronomy 9, 143 (2019)

26. Ertani, A., Cavani, L., Pizzeghello, D., Brandellero, E., Altissimo, A., Ciavatta, C., Nardi, S.: Biostimulant activity of two protein hydrolyzates in the growth and nitrogen metabolism of maize seedlings. J. Plant Nutr. Soil Sci. 172, 237-244 (2009)

27. Afolabi, O.O.D., Sohail, M., Cheng, Y.-L.: Optimisation and characterisation of hydrochar production from spent coffee grounds by hydrothermal carbonisation. Renew. Energy 147, 1380-1391 (2020)

28. Ischia, G., Fiori, L.: Hydrothermal carbonization of organic waste and biomass: a review on process reactor, and plant modeling. Waste Biomass Valoriz. 12, 2797-2824 (2021)

29. Bonanomi, G., Sarker, T.C., Zotti, M., Cesarano, G., Allevato, E., Mazzoleni, S.: Predicting nitrogen mineralization from organic amendments: beyond C/N ratio by 13C-CPMAS NMR approach. Plant Soil 441, 129-146 (2019)

30. Brassard, P., Godbout, S., Raghavan, V.: Soil biochar amendment as a climate change mitigation tool: key parameters and mechanisms involved. J. Environ. Manage. 181, 484-497 (2016) 
31. Ding, F., Van Zwieten, L., Zhang, W., Weng, Z., Shi, S., Wang, J., Meng, J.: A meta-analysis and critical evaluation of influencing factors on soil carbon priming following biochar amendment. J. Soils Sedim. 18, 1507-1517 (2018)

32. Ameloot, N., De Neve, S., Jegajeevagan, K., Yildiz, G., Buchan, D., Funkuin, Y.N., Prins, W., Bouckaert, L., Sleutel, S.: Shortterm $\mathrm{CO} 2$ and $\mathrm{N} 2 \mathrm{O}$ emissions and microbial properties of biochar amended sandy loam soils. Soil Biol. Biochem. 57, 401-410 (2013)

33. Cervera-Mata, A., Pastoriza, S., Rufián-Henares, J.Á., Párraga, J., Martín-García, J.M., Delgado, G.: Impact of spent coffee grounds as organic amendment on soil fertility and lettuce growth in two Mediterranean agricultural soils. Arch. Agronomy Soil Sci. 64, 790-804 (2018)

34. Sant'Anna, V., Biondo, E., Kolchinski, E.M., da Silva, L.F.S., Corrêa, A.P.F., Bach, E., Brandelli, A.: Total polyphenols, antioxidant, antimicrobial and allelopathic activities of spend coffee ground aqueous extract. Waste Biomass Valoriz. 8, 439-442 (2017)

35. Cruz, S., Marques dos Santos Cordovil, C.S.C.: Espresso coffee residues as a nitrogen amendment for small-scale vegetable production. J. Sci Food Agric 95, 3059-3066 (2015)

36. Cruz, R., Mendes, E., Torrinha, Á., Morais, S., Pereira, J.A., Baptista, P., Casal, S.: Revalorization of spent coffee residues by a direct agronomic approach. Food Res. Int. 73, 190-196 (2015)

37. Cervera-Mata, A., Navarro-Alarcón, M., Delgado, G., Pastoriza, S., Montilla-Gómez, J., Llopis, J., Sánchez-González, C., RufiánHenares, J.Á.: Spent coffee grounds improve the nutritional value in elements of lettuce (Lactuca sativa L.) and are an ecological alternative to inorganic fertilizers. Food Chem. 282, 1-8 (2019)

38. Drake, T., Keating, M., Summers, R., Yochikawa, A., Pitman, T., Dodd, A.N.: The cultivation of Arabidopsis for experimental research using commercially available peat-based and peat-free growing media. PLoS ONE 11, e0153625 (2016)

39. Gruber, B.D., Giehl, R.F.H., Friedel, S., von Wirén, N.: Plasticity of the Arabidopsis root system under nutrient deficiencies. Plant Physiol. 163, 161-179 (2013)

40. Vidal, E.A., Moyano, T.C., Canales, J., Gutiérrez, R.A.: Nitrogen control of developmental phase transitions in Arabidopsis thaliana. J. Exp. Bot. 65, 5611-5618 (2014)

41. Ikram, S., Bedu, M., Daniel-Vedele, F., Chaillou, S., Chardon, F.: Natural variation of Arabidopsis response to nitrogen availability. J. Exp. Bot. 63, 91-105 (2012)

42. Duong, T.T.T., Penfold, C., Marschner, P.: Amending soils of different texture with six compost types: impact on soil nutrient availability, plant growth and nutrient uptake. Plant Soil 354, 197-209 (2012)

43. Boyes, D.C., Zayed, A.M., Ascenzi, R., McCaskill, A.J., Hoffman, N.E., Davis, K.R., Görlach, J.R.: Growth stage-based phenotypic analysis of arabidopsis: a model for high throughput functional genomics in plants. Plant Cell 13, 1499-1510 (2001)

44. Massaya, J., Prates Pereira, A., Mills-Lamptey, B., Benjamin, J., Chuck, C.J.: Conceptualization of a spent coffee grounds biorefinery: a review of existing valorisation approaches. Food Bioproducts Process 118, 149-166 (2019)

45. Coelho, C., Ribeiro, M., Cruz, A.C.S., Domingues, M.R.M., Coimbra, M.A., Bunzel, M., Nunes, F.M.: Nature of phenolic compounds in coffee melanoidins. J. Agric. Food Chem. 62, 7843-7853 (2014)

46. Sato, T., Takahata, T., Honma, T., Watanabe, M., Wagatsuma, M., Matsuda, S., Smith, R.L., Itoh, N.: Hydrothermal extraction of antioxidant compounds from green coffee beans and decomposition kinetics of 3-o-caffeoylquinic acid. Ind. Eng. Chem. Res. 57, 7624-7632 (2018)
47. Arauzo, P.J., Lucian, M., Du, L., Olszewski, M.P., Fiori, L., Kruse, A.: Improving the recovery of phenolic compounds from spent coffee grounds by using hydrothermal delignification coupled with ultrasound assisted extraction. Biomass Bioenergy 139, $105616(2020)$

48. Leng, L., Yang, L., Leng, S., Zhang, W., Zhou, Y., Peng, H., Li, H., Hu, Y., Jiang, S., Li, H.: A review on nitrogen transformation in hydrochar during hydrothermal carbonization of biomass containing nitrogen. Sci. Total Environ. 756, 143679 (2021)

49. Ortíz-Castro, R., Contreras-Cornejo, H.A., Macías-Rodríguez, L., López-Bucio, J.: The role of microbial signals in plant growth and development. Plant Signal Behav. 4, 701-712 (2009)

50. A.L. García-García, F.J. García-Machado, A.A. Borges, S. Morales-Sierra, A. Boto, D. Jiménez-Arias, Pure organic active compounds against abiotic stress: a biostimulant overview. Front. Plant Sci. 11 (2020)

51. Mohammadipour, N., Souri, M.K.: Beneficial effects of glycine on growth and leaf nutrient concentrations of coriander (Coriandrum sativum) plants. J. Plant Nutr. 42, 1637-1644 (2019)

52. Zargar Shooshtari, F., Souri, M.K., Hasandokht, M.R., Jari, S.K.: Glycine mitigates fertilizer requirements of agricultural crops: case study with cucumber as a high fertilizer demanding crop. Chem. Biol. Technol. Agric. 7, 19 (2020)

53. Souri, M.K., Hatamian, M.: Aminochelates in plant nutrition: a review. J. Plant Nutr. 42, 67-78 (2019)

54. D. Jiménez-Arias, F.J. García-Machado, S. Morales-Sierra, A.L. García-García, A.J. Herrera, F. Valdés, J.C. Luis, A.A. Borges, A Beginner's guide to osmoprotection by biostimulants. Plants $\mathbf{1 0}$ (2021)

55. Ljungdahl, P.O., Daignan-Fornier, B.: Regulation of amino acid, nucleotide, and phosphate metabolism in Saccharomyces cerevisiae. Genetics 190, 885-929 (2012)

56. Godard, P., Urrestarazu, A., Vissers, S., Kontos, K., Bontempi, G., van Helden, J., André, B.: Effect of 21 different nitrogen sources on global gene expression in the yeast saccharomyces cerevisiae. Mol. Cell. Biol. 27, 3065-3086 (2007)

57. Björkeroth, J., Campbell, K., Malina, C., Yu, R., Di Bartolomeo, F., Nielsen, J.: Proteome reallocation from amino acid biosynthesis to ribosomes enables yeast to grow faster in rich media. Proc. Natl. Acad. Sci. 117, 21804 (2020)

58. S. Balzan, G.S. Johal, N. Carraro, The role of auxin transporters in monocots development. Front. Plant Sci 5 (2014)

59. Foster, R.J., McRae, D.H., Bonner, J.: Auxin-induced growth inhibition a natural consequence of two-point attachment. Proc. Natl. Acad. Sci. USA 38, 1014-1022 (1952)

60. Smith, S., Zhu, S., Joos, L., Roberts, I., Nikonorova, N., Vu, L.D., Stes, E., Cho, H., Larrieu, A., Xuan, W., Goodall, B., van de Cotte, B., Waite, J.M., Rigal, A., Ramans Harborough, S., Persiau, G., Vanneste, S., Kirschner, G.K., Vandermarliere, E., Martens, L., Stahl, Y., Audenaert, D., Friml, J., Felix, G., Simon, R., Bennett, M.J., Bishopp, A., De Jaeger, G., Ljung, K., Kepinski, S., Robert, S., Nemhauser, J., Hwang, I., Gevaert, K., Beeckman, T., De Smet, I.: The CEP5 peptide promotes abiotic stress tolerance, as revealed by quantitative proteomics, and attenuates the AUX/IAA equilibrium in Arabidopsis. Mol. Cell. Proteom. 19, 1248-1262 (2020)

Publisher's Note Springer Nature remains neutral with regard to jurisdictional claims in published maps and institutional affiliations. 